\title{
Themis en de tuinen van Rome
}

Citation for published version (APA):

Spruit, J. E. (1989). Themis en de tuinen van Rome. Kluwer. https://doi.org/10.26481/spe.19890609js

Document status and date:

Published: 09/06/1989

DOI:

10.26481/spe.19890609js

Document Version:

Publisher's PDF, also known as Version of record

\section{Please check the document version of this publication:}

- A submitted manuscript is the version of the article upon submission and before peer-review. There can be important differences between the submitted version and the official published version of record.

People interested in the research are advised to contact the author for the final version of the publication, or visit the DOI to the publisher's website.

- The final author version and the galley proof are versions of the publication after peer review.

- The final published version features the final layout of the paper including the volume, issue and page numbers.

Link to publication

\footnotetext{
General rights rights.

- You may freely distribute the URL identifying the publication in the public portal. please follow below link for the End User Agreement:

www.umlib.nl/taverne-license

Take down policy

If you believe that this document breaches copyright please contact us at:

repository@maastrichtuniversity.nl

providing details and we will investigate your claim.
}

Copyright and moral rights for the publications made accessible in the public portal are retained by the authors and/or other copyright owners and it is a condition of accessing publications that users recognise and abide by the legal requirements associated with these

- Users may download and print one copy of any publication from the public portal for the purpose of private study or research.

- You may not further distribute the material or use it for any profit-making activity or commercial gain

If the publication is distributed under the terms of Article $25 \mathrm{fa}$ of the Dutch Copyright Act, indicated by the "Taverne" license above, 
Themis en de tuinen van Rome 



\section{Themis en de tuinen van Rome}

rede uitgesproken bij de aanvaarding van her ambe wan bijzonder hoogleraar in de Rechtsgeschiedenis aan de Rijksuniversiteit Limburg te Maastricht op vrijdag 9 juni 1989

door

Prof. Mr. J.E. Spruit

Kluwer-Deventer - 1989 
(6) 1989,1 . I. Spruit, Milverstum

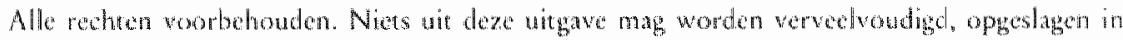

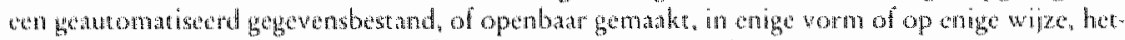
xit alekronisch, mechanisch, door lowocopicen, opramen, of op cnige andere manier, zonder

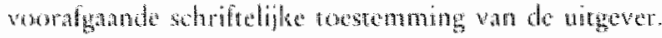

Voor zover he maker wan kopien un deze uitgave is toxyestan op grond van arikel l6b Au-

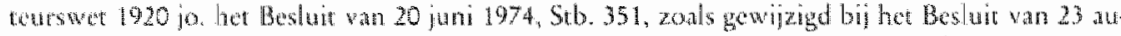
gustus 1985, 5th. 471 an artikel 17 Auteurswer 1912, dient men de darvoor wetclik versehuldig. de vargoedingen te voldoet an de Stichting Reprorech (Postbus 882, 1180 A W Amstelven).

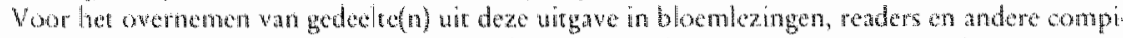

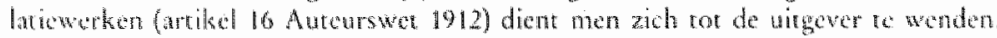


Mijnheer de Rector,

geachte leden van het Bestuur van de

Stichting Wetenschappelijk Onderzoek Limburg,

zeer welkome toehoorderessen en toehoorders,

\section{Inleiding}

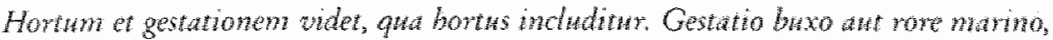

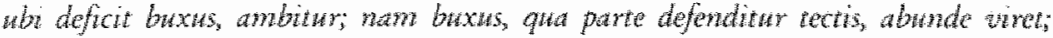
aperto calo apertoque vento et quanquam longingua aspergine maris inarewcit. Adiacet gestationi interiore circamitu winea tenera et tombrosa, nudisque ctiam pedibus mollis et cedens. Hortum morus et ficus frequens westit, quartan arbarum illat wel maxime ferax terra est, malignior ceteris,

De eetkamer ziet uit op een tuin en een laan die de ruin omsluit. De laan wordt omgeven door buksen, of door rozemarijn waar buksen ontbreken. Want de buks groeit weelderig zolang hij beschermd wordt door de gebouwen, maar werdort onder de open hemel, in de open wind of door het spatten van de zee, hoewel die op afstand ligt. Langs de binnenzijde van de laan ligt een jonge lommerrijke wijngaard, voor een blote voet zelfs zacht en meegevend. De tuin is rijkelijk begroeid met moerbei en vijg. Voor die bomen is de grond daar bil uirstek geschikt, voor andere te schraal,

aldus beschrijft Plinius de tuin, waarop hij vanuit de eetkamer van zijn tegen de zee aangelegen villa in Laurentum uitzicht heeft. ${ }^{1}$ Hij was een wan die Romeinen over wier exquise villa's tot in de huidige tijd gesproken wrordt: men denke aan Lucullus, beroemd om zijn eetculruur en rijke ruinen ${ }^{2}$, en Maecenas, in wiens wijds uitwaaierende park keizers als Augustus en Tiberius zich gaarne terugtrokken. ${ }^{3}$ Maar ook de minder vermogende Romein was gesteld op een tuin, al was het maar om er groenten te kwelken. ${ }^{4}$ Over tuinen, hum inrichting en beplanting in het oude Rome lezen wij bij Cato, Varro, de beide

1. Plin., Epist. 2,17, 14-15; van zin willa in Tusculum beschriglt hij elders de $x y s t w 5(5,6,16-19)$ en de bippodrontas, $(5,16,32,36)$.

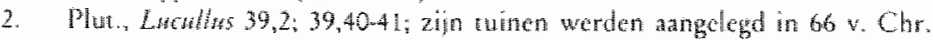

3. Suet, Atag 72,$2 ; T i 2,15,7 ;$ Nero 31,$1 ; 38,2$.

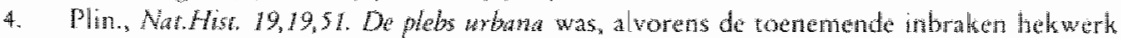

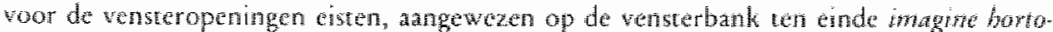

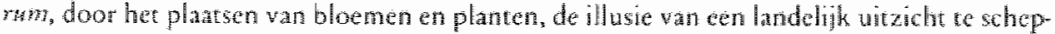

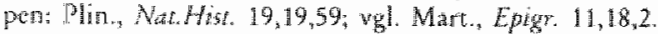


Plini, Catullus, Horatius en vele anderen"; voorts worden in inscripties vaak tuinen genoemd. De archaeobotanie heeft in de afgelopen jaren veel aan her licht gebracht over de architectur en de aard van de beplanting van de Romeinse tuin. Maar de Romeinse juristen? Wat hebben zij bigedragen aan onze kennis over de plaats van de tuin in her maatschappelijke leven en de rechtscultuur van hun tijd.

Gevragd naar de betekenis van zuinen voor het recht, zal de hedendagse jurist in het algemeen niet veel anders kunnen doen dan een enigszins relativerend antwoord geven. Anders dan de tuinarchitect of de hovenier, voor wie de tuin dagelijks een zelfstandig worwerp van visie, beleid en bewerking is, zal de jurist een enigzzins afstandelijker houding inzake de betekenis van de tuin voor het recht innemen. Hier en daar speelt de tuin in de regelgeving en in de jurisprudentie wel een rol, maar in het algemeen is deze toch van ondergeschikte betekenis. In het strafrecht in het kader wan overtredingen betreffen. de de veldpolitie, war het an niet dartoe gerechtigden verboden wordt nieruitvliegend pluimgedierte en vee in tuinen te laten lopen. ${ }^{6}$ In het burgerlijtk recht war het betreft de rechten en verplichtingen tussen eigenaren van naburige erven: muren ter afscheiding tussen tuinen worden geacht gemeen te zijn en de onderhoudskosten worden naar evenredigheid van ieders recht gedragen; woorts bestaat er in de steden en dotpen een wettelijke afsluitingsplicht tussen eigenaren van aangrenzende tuinerven. ${ }^{7}$ Betreft het schade, toegebracht aan tuin- of veldvruchten, dan is de kantonrechter competent. ${ }^{8}$ In recente bijzondere wetgeving speett de tuin een zwaardere rol, met name wanneer het gaat om bescherming van gewassen in het kader van de tuinbouw." Evenals vroeger is ook thans een twin slechts zelden zelfstandig het object van rechtshandelingen: het gaat dan immers meestal om een kadastraal exact omschreven perceel warop mogelijk ook een tuin is aangelegd. Voorts kunnen zich, precies als in de oudheid, allerlei andere $k$ westies voordoen: burenruzies

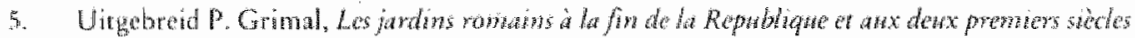

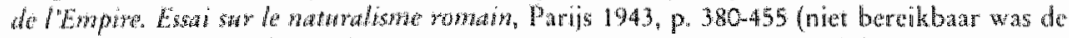

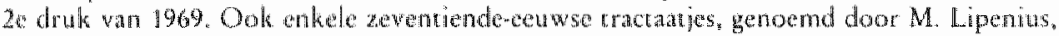

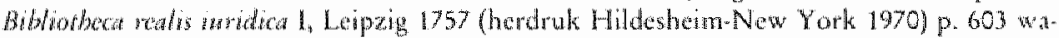

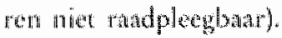

6. Wetbock wan Sre, art $458-459$.

7. D.W. att. 681 lid $1 ; 683 ; 690$.

8. Wer R.O. art. 39 sub Wetboek van Rurg. Rv. art. 98 sub 1; Zi voorts HR 24 novernber 1967, NJ $1968,107$.

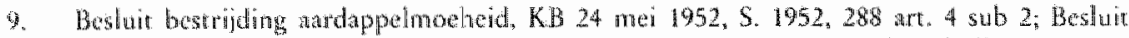
bestrifing wrtatekte. KB 22 november 1973, 5. 1973, 591, art. 6, Bloembollenziektewet $1937,5.1937,6391$ ant 9 sub 2; Bestrijdingsmiddelenbesluti, KB 25 juli 1964, 5. 1964, 328, art. 5a sub 1. 
ontstaan naar anlleiding van overhangende takken of onderscherende wortels, erfscheidingsproblemen, beplanting door een ander dan de rechehebbende op het terrein en de gevolgen daarvan, de mogelikheid van het vestigen van een recht van opstal op de grond ten einde de zakelijk gerechtigdheid op het daarop gegroeide bij een ander dan de grondeigenaar te leggen, allerhand arbeidsrechtelijke geschillen tussen de tuinbezitter en ziln tuinlieden. Het is maar een greep uit een arsenaal van mogelijkheden, mogelikheden overigens die in het algemeen niet samenhangen met de tuin als zodanig, maar met grondbezitsverhoudingen in het algemeen.

Nog moeilijker wordt het om tuin en recht in rechtshistorisch perspectief te belichten, zeker als het om de oudheid en de middeleeuwen gat. De bronnen zijn schaars. Moge er ook dank zij de literaire en epigrafische bronnen, gecombineerd met archeologisch onderzoek, over de de beplanting en de architectur wan de tuin in de oudheid steeds dieper gaand inzicht verkregen zijn, ook hier kan de jurist om precies dezelfde redenen als zojuist geschetst niet het hoogste woord hebben. Het is in dit opzicht met de Romeinse iurisconsultial niet weel anders geweest als met hun moderne confrères: zij hebben in hun wetenschappelijk oeuvre nauwelijks andacht gegeven aan de tuin als zelfstandig object van rechtsberrekkingen. Wel hielden zij zich bezig net het wijd uiteenlopend spectrum van rechtsverhoudingen waarin ook toen bebouwde en onbebouwde percelen grond het object waren. Uit dien hoofde vinden we in de juridisch-literaire traditie een rijke casuistick, warvan het pratimm, de fundus, de ager, de locus of de areat een centrale rol speelt. In vele van deze gevallen heeft mogelijk een dergelijk perceel grond gedeeltelijk ook een tuin omvat, in de zin wan een omheind stuk land, waar ooft, groente, bloemen en planten voor eigen gebruik dan wel met commercieel oogmerk verbouwd werden. ${ }^{10}$ En als de juristen gevallen behandelen waarin het woonhuis een rol speelt, zal het in de praktijk impliciet waak ook om een fraaie geperistyleerde binnentuin, een viridarizm dat licht en luch aan de architecuur verleende, zijn gegaan. Aangezien de juristen dit nier nader aangeven, is behandeling van dit soort problematiek in het kader van een beschouwing over tuin en reche tamelijk speculatief.

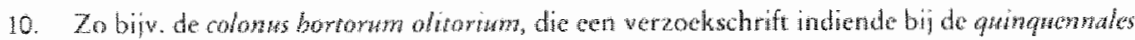

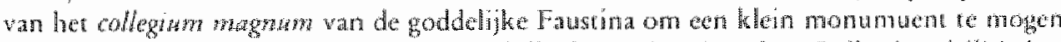

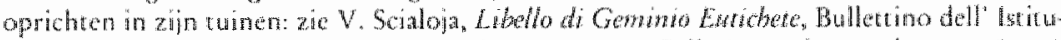

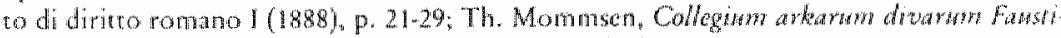
warkn, Gesamme Schriten III, Berlijin 1907 (herdruk 1965), p.71.74. 


\section{De juridische bronnen}

Op vastere bodem bevinden wij ons met juridische teksten, waarin de tuin of de tuinbewerkers met zovel woorden worden genoemd. Daar war de juw risten bijv. de bortus, de hortulus, het windarium, het olitoriwn, de hortulamus, de olitor of de topiarius ten tonele voeren, is het zeker dat zij bezig waren met een tuin in de eigenlijke zin van het woord. Dit impliceert niet, dat de tuin in her denken van de Romeinse juristen als zodarig een rol wan grote betekenis heeft gespeeld. De tuin verschijnt sporadisch in het tekstmateriaal, en dan nog in de marge van de juridische casuistiek, meestal als woorbeeld om een beparalde stelling te illustreren. Maar juist ondat de tuin hier en daar wordt genoemd als voorbeeld in een betoog of als onderwerp van een kleine exegetische beschouwing, valt ert toch over de tuin in het recht wel iets te zeggen. Op grond van antiek- juridisch tekstmateriaal dat tot dusver niet de aandacht van de kunsthistoricus of de archeoloog heeft gehad, kunnen vanuit rechtsgeleerd perspectief wellicht nog enige aarvullingen omtrent de plaats van de tuin in het maatschappelijk verkeer worden gegeven.

Dit antieke reksmateriaal is afkomstig uit juridische bronnen wan uiteenlopende aard. In de eerste plats uit beward gebleven fragmenten van ge schriften van juristen uit de eerste eeuwen van onze jaartelling, warbij her opvallend is dat vooral Domitius Ulpianus (gest. 228) de tuin nogal eens in zijn beschouwingen betrekt. Voorts zijn er enkele verordeningen (constitutio nes) uit de latere keizertijd, die tuinen en tuinlieden tot voorwerp hebben. Tenslotte komt de tuin enkele malen voor als object van een in een akte vastgelegde rechtshandeling, bijv, een schenking of een uiterste wilsbeschikking. Door archeologische speurzin is de oorkonde van een dergelipke rechtshandeling in enkele gevallen teruggevonden of is de op steen geinscribeerde tekst wecr boven gekomen. Aldus kunnen wij een direct inzicht verkrigen in enkelo facetten van de antieke maarschappelijke praxis rondom de tuin.

\section{Heredium en Hortus}

Evenals de Gricken, ja zich in vele opzichten in hun cultuur spiegelend, kenden de Romeinen al vroeg een tuincultuur. Reeds voor het vroege uur van hun beschaving wordt melding gemaakt van de anwezigheid van tuinen. Ovidius dicht het paleis van Tarquinius Superbus reeds een fraaie tuin met gemengde kruiden en een murmelend watertje toe: 
Hortus odoratis saberat cultissimus berbis

sectus bumum riwo lene sonantis aquael

Beneden lag een ruin die kunstrol beplant was met geurige kruiden, de bodem gekliefd door een beek met zachtbruisend water.

Mer Plinius, die mededeel dat in de Lex XII Tabularum het woond heredism voorkwam en daar de beperktere betekenis had van wat in de eerste eeuw met het woord hortus werd angeduid ${ }^{12}$, bevinden wij ons op minder mythische bodem. Wanneer wat hij zegt juist is, dan duidde in de vroege rechtstaal het woord beredium meer in engere zin op wat later, in zijn tijd, bortus heette, d. w.z. op ongebouwd onroerend goed buiten de stad. Het had dus betrekking op ean perceel grond dat in het Jatere juridische sprakgebruik werd angeduid als een praedium nisticum. Hortus werd in die vroege tijd echter gebruikt voor wat in Plinius" tijd willa, boerehoeve, heette. Vanuit de grondbetekenis van het woord bortus, dat naast de omheining vooral ook het ombeinde perceel zelf aanduidde ${ }^{13}$, handhaafde het zich in het taalgebruik met een verandering van het oorspronkelijke semantische veld. Inderdaad wordt in de klassieke juridische teksten bortus gebrukt ter anduiding van een omheind en ongebouwd perceel, ongeacht of dit gelegen is binnen de stad of dat het gesitueerd is buiten de banmijl van Rome, ten plattelande. Ulpianus spreekt zich hierover met zoveel woorden uit: "Verder moet gezegd worden dat ook tuinen, indien deze tussen gebouwen zijn gelegen, onder de aanduiding 'stedelijke percelen' vallen. Maar het is duidelijk dat als tuinen voor het grootste dee! gericht zijn op het verkrijgen van rendement, bijv. wijngaarden of moestuinen, deze niet 'stedelijk' zijn. ${ }^{14}$ Beslissend is derhalve niet meer de vraag of het perceel gelegen is in de stad of ten plattelande, maar of het een al dan niet gebouwd perceel betreft. De hoedanigheid, de bestemming van het perceel in $\mathrm{kw}$ estie is beslissend, niet de ligging in of buiten de stad. Ongeacht de ligging

11. Ovidus, Fats 2, 704705; wgl. Mlin., Nat. Has. 1, 54,6; Val. Max. 7,4,2; Dion. Malic, 4,56; Plin., Nat.Hist. 1953,169 .

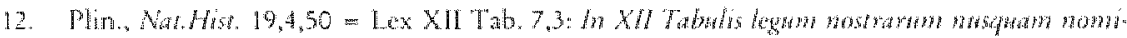

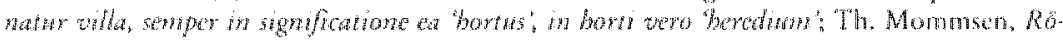

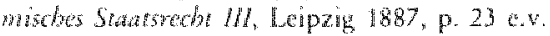

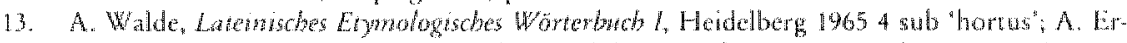

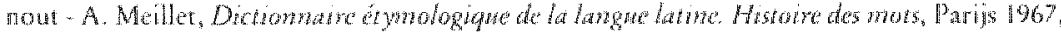

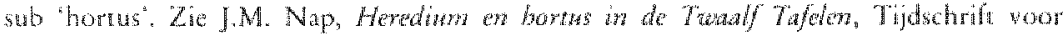
Rechtsgeschidenis $5(1918-1919), 0.390399$.

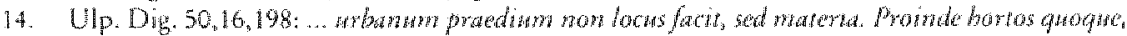

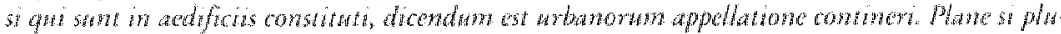

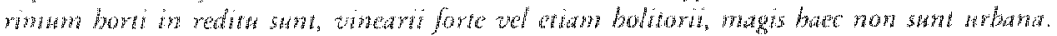


zal de bij een huis gelegen siertuin (viridarium in het algemeen als een pradt. wm whansm, de moestuin in het algemeen als een praeditm mustrom behan. deld zijn. In concrete situaties was het van belang vast te stellen wat het karakter van de betrokken tuin was, in het bijonder wanneer het ging om het westigen van erfdienstbatheden: serviutes praediorum urbanorum werden in het bijzonder gevestigd op fundi urbuni; servitutes praediorum rusticorum waren voorbehouden an fundi rustici. ${ }^{15}$ De onderscheiding speelt een rol o.a. bij de vestiging van bepaalde typen erfdienstbaarheden en voor hun verjaringsmogelijkheden.

De vraag naar het al dan niet gebouwd zijn van de percelen was oorspronkelik ook beslissend voor de toepasselijkheid van de actio finium regundorum, de grensregelingsachie. Zij werd nog in Cicero"s tijd niet geschikt geache, wan neer het om geschillen bereffende praeda urbana - binnen de stad gelegen percelen - ging ${ }^{16}$ : deze waren in het algemeen immers omheind en hadden niet de tussen pradia rustica gebruikelijke ambitus, de niet bebouwde, gemeenschappelijk toegankelijke en voor het keren van het span ploegossen bestemde grensstrook van ongeveer viyf voet. Deze beperkingen gingen in het klassieke recht verloren, omdat de omvangrijke landgoederen in en bij de steden niet altijd volledig omheind of ommurd meer waren: het is juist de uir gestrektheid van de tuinen (latitudo bortorum), zegt Paulus, die de mogelijkheid met zich medebrengt, dat ook binnen de stad de actio finium regundorwm toepassing kon vinden, namelijk in die situaties dat stedelijke tuinen een confiniwm hebben, warover tussen de eigenaren een geschil ontstaat. ${ }^{17}$

\section{Tuin en buis als eenheid}

In de lati-Republiekeinse taalschat heeft het woord bortus zich gehandhatal ter anduiding van een omheinde ruimte alsmede, in een enkel geval, ter aan-

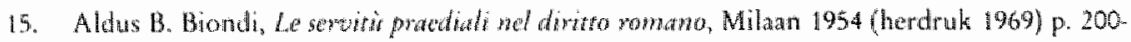
213.

16. Cifero, Topia 4,23; 10,4,3; Ulp. Dig. 10,1,2,pr.; vgl. Ulp. Dig. 10,1,4,10 de argumentate

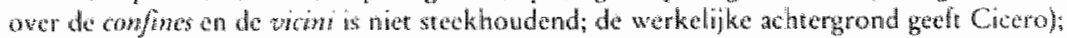
A. Warson. The Later of Property is the Leter Rom Republic, Oxford 1968 (herdruk Aalen $1984 \%, \mathrm{p} .11 \mathrm{1} \% 11 \%$

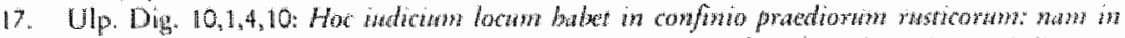

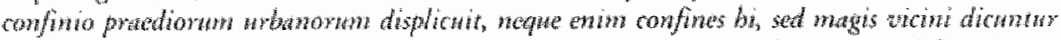

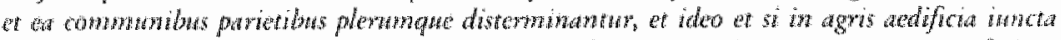

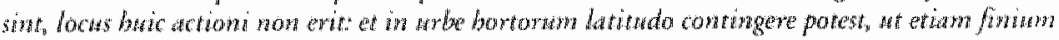
regurdoram age posit. 
duiding van de omheining zelf. ${ }^{18} \mathrm{Al}$ woeg in de geschiedenis speelde de tuin in eenheid met het huis een centrale rol in het familieleven. In Pompeji is dit nog te zien. De in elegante hellenistische stijl opgetrokken huizen, vele ervan gebouwd door vermogende Samnieren in de ze eeuw . Chr., hadden al ruime tuinen, soms bestemd voor her verbouwen van produkten, soms opgezet als fleurige van lage beplanting voorziene door een peristylum omgeven siercuinen. ${ }^{19}$ Echte siertuinen op wat grotere schaal ontstonden in Rome vanaf de rweede eeuw v. Chr; kleinere tuinen waren er altijd al geweest. Indien hij nitet in één van de wele woonkazernes zijn leven moest slijten of tot het leger van daklozen behoorde, had ook de minder vermogende Romein graag de beschikking over een omheinde en bij voorkeur schaduwrijke rumte on het huis op warme dagen te kunnen ontwluchten. Tot de tuinen warover men bij Cicero, Plimius en nog anderen leest, of die in Pompeï, Herculanum en elders zijn blootgelegd, behoren zowel de lommerrijke van fraaie beelden, fresco's en nymphaea voorziene percelen van vermogende lieden alsook de bescheiden uitloopjes achter de eenvoudige woning wan hard werkende kooplui. In het eerste geval waren het of rume, door zuilen omgeven siertuinen dan wel grote, af wisselend opgezette parken met een warièteit aan beplanting. De fraiste tuinen bevatten naast een breed spectrum van 'klassieke' bloemen een verscheidenheid aan soorten rozen, violen, crocussen, lelies, byacinthen en narcissen - ook een lage begroeing met waar dat mogelijk was klimop en wijnanken, alsmede een scala van planten als juniperus, viburnum en, ter markering van architectonische vlakverdelingen, buxus. Tot de weell woorkomende hoge bomen behoorde de palm, de cypres, de pijnboom, de plataan. ${ }^{20}$ Afwisseling werd er gebracht door een parkachtige annleg, warin boomgroepen, bloemenvelden, grasgazons, waterpartijen met kunstmatige grotten en nymphaea, fraai gebeeldhouwde fonteinen, wandelpaden en lommerrijke, van soms uit Griekenland geimporteerde beelden - voorall van Venus, de beschermgodin van de tuin en van de ofitores ${ }^{21}$ - voorzicne lanen het welbehagen van bewoners en bezoekers optimaliseerden. In een dergeligke entourage trokken vooranstaande en vermogende Romeinen in Rome en omgeving, evenals in Pompeji en andere provinciesteden, hun woonverblijwen en zomer-

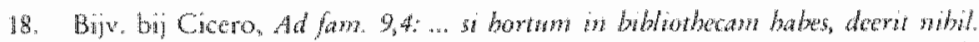

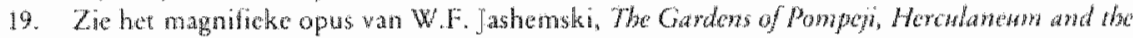

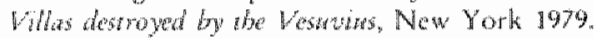

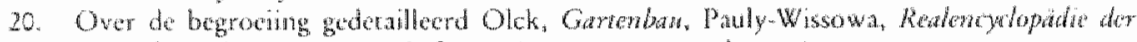

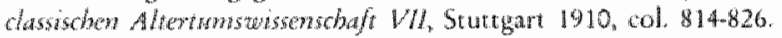

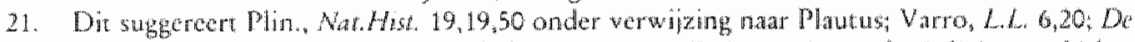

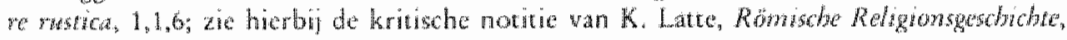
Misnchen 1960, p. 187. 
huizen op. Daar werd gegeten en gedronken, gezeten of gelegen op banken van het tuintriclinim. De anticke literaire bronnen getuigen hoe men daarbij soms genoot van het mild getokkel op de lyra of de cythara, dan wel wegmijmerde op de ifle tonen wan de syrinx, tibia of aulos. ${ }^{22}$ Neigde men eerder tot literair vermaak, dan luisterde men naar het voorlezen van wat poëzie, van scènes uit een boek, of men liet zich amuseren door het opvoeren van een komedie; of het moest zijn dat men de voorkeur gaf an eer wervelend optreden van Spanse dansmeisjes. ${ }^{23}$

Maar ook voor de om zijn dagelijkse existentie strijdende koopman met een winkeltje of een klein woonhwis was het hebben wan een tuintje een belangrijke luxe ten einde het leven dragelijk te maken. Lagen deze perceeltjes tegen elkaar an, dan kon dit tot allerhande verwikkelingen aanleiding geven. Men leze slechts de komedies van Plautus om te zien welke penibele situaties konden onstaan door een va et vient via de achtertuin. ${ }^{24}$ Voor rijk en arm gold dat tal van hoogtijdagen in het familiale en sociale leven alom in de tuin werden gevierd.

Dat huis en tuin in de Romeinse conceptie sterk samenhorem, dat de tuin als één geheel met het huis werd beschouwd, is ook nawijsbaar in de juridische teksten, die in dit geval in meerderheid van Ulpianus afkomstig zijn. Zo werd men ingeval men werd aangewezen tot procesvertegenwoordiger door iemand die in zijn tuin verkeerde 25 , beschouwd als een procurator praesentis, d.w. 2 . als een procesvertegenwoordiger die door de principaal zelf werd voorgesteld. Papinanus illustreert de samenhang van huis en tuin aan de hand van een ander gevall: een huiseigenaar koopt de tuin van zijn buurman die tegen zijn woning aanligt. Vervolgens maakt hij zijn testament, waarin hij bij legaat zijn huis aan iemand vermakk. Na zijn dood ontstaat twist cussen de erfgenamen en de legataris over de omvang van het legat: omvat het legaat van het huis nu wel of niet de daarmede én geheel uitmakende tuin? In overeenstemming met de rechtsgeleerde adviespraktijk stelt Papinianus zich op het standpunt dat, als de erflater de ruin had gekocht om zijn huis hefelijker te maken en er gezonder te kunnen leven, en als hij voorts via zin huis toegang tot de twin had en, in het algemeer gesproken, de tuin een wezenlijke toevoeging aan het

22. Mart. Epigy. 5,8, zie voor muztck an da dis vooral Petron., Sat. 31-35, over de muzick

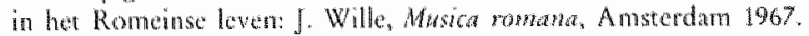

21. Plin., Aptit. $1,15,3 ; 3,1,9 ; 9,36,4$.

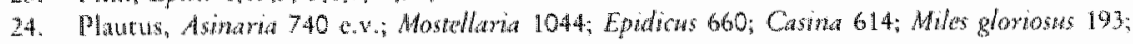
340; Stichos 437; 452 : Persid 445.

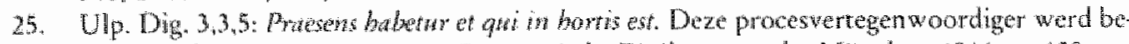
handeld als agmitor. M. Kaser, Das romigho Zivilprozessebr, München 1966, p. 159. 
huis was, het legaat van het buis mede de tuin omvatte. ${ }^{26}$ In deze redenering is de gedachte van de verbondenheid wan huis en tuin sterk aanwezig, en is de samenhang crucial voor de interpretatie van de uiterste wil van de enflater. Verder past zij in de algemene visie van de klassieke junisten dat vermeerderingen en verminderingen die tussen het maken van het testament en de dood van de erflarer plaatswinden ten aanzien van een specifiek omsehreven gelegateerde zaak, ten voor-c.q. nadele van de legataris komen. ${ }^{27}$

Andere situaties illustreren de eenheidsgedachte nog sterker: de Lex Cornelia de imirusis, een wet uitgevaardigd in $81 \%$. Chr". onder Sulla, richt zich tegen physieke mishandeling in de eigen ongeving en is in zekere zin een bescherming van wat men tegenwoordig aanduidt als het huisrecht. Hoe ver reikte deze bescherming? Ulpianus belicht enkele aspecten wan de huisvredebreuk in zijn Edictscommentaar. Hij stelt dat het begrip "huis" geinterpreteerd moet worden als domicilie, ongeache of iemand dit als eigenaar, vruchtgebruiker, huurder of bruiklener bewoont. ${ }^{28}$ Wordt de berrokkene geslagen of gestompt in zijn eigen tuin, dan valt dit delict onder de Lex Comelia de iminriis. ${ }^{29}$ Dezelfde eenheidsconceptie houdr. Ulpianus erop na in zijn beschouwing over het instellen van hoger beroep: de appellant dient dit normal binnen een dag in te stellen bij de rechter die de uitspraak in eerste instantie heeft gedaan en die daartoe dan wel op een openbare plats bereikbaar moet zijn. Het is niet vereist dat de appellant extra inspanningen moet verrichten, bijv. door zich te vervoegen an diens huisadres of diens tuin binnen te lopen. ${ }^{30}$

Tenslotte geefr Ulpianus in een geheel ander verband nog een interpretatie van het begrip 'sub eodem tecto', 'onder hetzelfde dak'. Hij doet dit in het kader van een beschouwing over het Senatusconsultum Silanianum (10 $\mathrm{n}$. Chr.), dat tortuur en bestraffing mogelijk makt van alle slaven die met hun gewelddadig om het leven gebrachte dominus "onder eén dak" woonden. ${ }^{31}$ Hoe moeten we deze terminologie nu precies verstan, zo vraagt thij zich af.

26. Pap. Dig. 32,91,5.

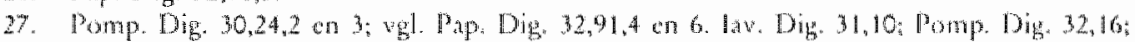

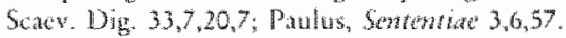

28. Ulp. Dig. $47,10,5,2$.

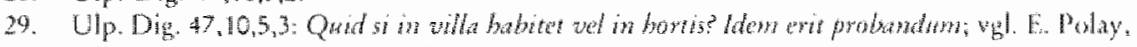

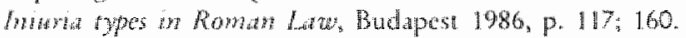

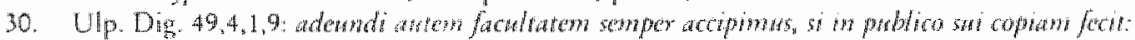

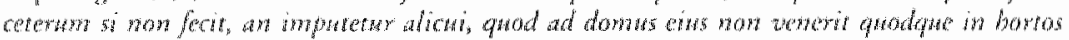

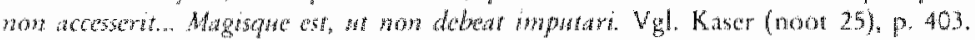

31. Ower dit Senat usconsulum Slananum en zijn latere verscherpingen zid lie. bij E. Voluera,

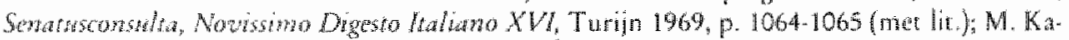

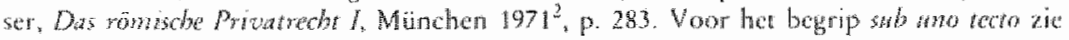

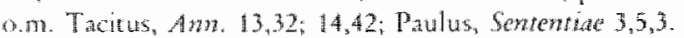


Betekent dit dat de betrokken slawen zich moeten hebben bevonden binnen dezelfde muren, binnen hetzelfde vertrek, binnen hetzelfde huis, dezelfde tuin of op hetzelfde landgoed? Ulpianus geeft een enigszins diffuus antwoord op deze wrags, dat rekening houdt met de concrete situatie. Zich aansluitend bif het standpunt van Sextus Cacilius zegt hij: alleen diegenen moeten als waren zij onder éen dak gestrafti worden die zich op een plek bevonden war zij het geroep konden horen, moge her overigens zo zijn dat niet iedereen overal ge. hoord kan worden, aangezien de én cen wat sterkere stem heeff dan de ander. In de loop wan de tijd wonden werscherpingen plaats van deze onmenselijke regel: in 532 concretiseert Justinianus het begrip "onder hetzelfde dak", onder argumentatie dat de oude juristen onzekerheid hadden laten bestan of daaronder ook de porticus of de atula - hier in de betekenis van audín, win - begrepen moesten worden, nog in die zin dat alle slaven die waar ook her geroep hadden kunnen horen en geen hulp hadden geboden, ter dood gebrache moesten worden. ${ }^{33}$ De exegese van Ulpianus en de tekst van de wet bevestigen beide het beeld dat de uin tot de strikt private sfeer behoort en word beschouwd als cen plaars war men, evenals in huis, afgeschermd wan het openbare leven, zichzelf kan zijn.

De eenheid wan huis en tuin, de conceptie van de integrale eenheid van percel en gebouw in die zin dat de werking van bepalde rechtsnormen zich van het gebouw ook uitstrekt over daarbijbehorende tuin, is in de latere christelijke tijd in een geheel ander werband ook bevestigd door Theodosius II en Valentinianus jegens degenen die hun toevlucht zochten in een christelijke kerk. Het asielrecht dat in de vroege keizertijd zwak ontwikkeld was en nier de sympathie van de Romeinse juristen had ${ }^{34}$, ontplooide zich rooral in de 5e eew onder christelijke invloed. Het asielrecht vond in de latere keizerlijke verordeningen erkenning als een tot de kerkelijke rechtssfeer behorend instituut; tal van details werden geregeld door de keizerlijke kanselarij. In 431 werd het astelrecht uitgebreid tot de directe omgeving van de kerk, onder de argumentatie dat het an geen enkele wluchteling toegestan was te eten, te slapen of de nacht doop te brengen in de teerk zelf of bij het altaar. Daarom zijn degenen die hun toevlucht zochten tor de om de kerk gelegen tuin, hof, zuilengalerij of anderszins, op dezelfde wijze beschermd als bevonden zij zich in

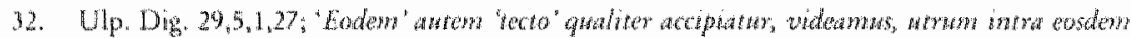

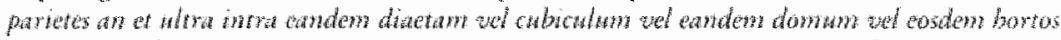

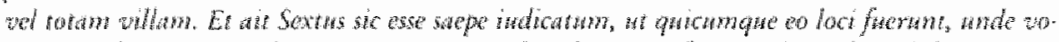

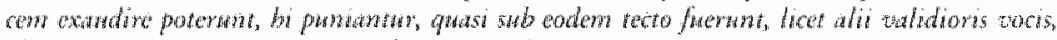

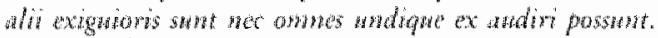

33. Cadex $6,35,12$ (anno 532$)$.

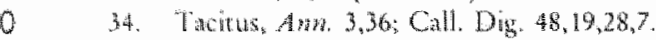


de kerk. ${ }^{35}$ Daarbij gold een absoluut werbod op het dragen van wapens op straffe van onmiddellijke verwijdering met behulp wan de sterke arm, ${ }^{36}$

De gedachte dat huis en ruin een eenheid vomen is in modernere concepties, in het bijzonder in onze eigen wetgeving, evenmin verlaten. Illustratief is bijv. de recente Wet van 26 oktober 1988 op de Telecommunicatievoorzieningen, warin ontheffing wordt verleend van de gedoogplicht betreffende de aanleg en de instandhouding van kabels ten dienste van de telecommunicaticinfrastructuren, wanneer het gaat om 'afgesloten tuinen on erven die met bewoonde percelen een geheel vormen'.37 Recente Koninklike Besluiten ter uitvoering van de Wet Geluidhinder 1979 hanteren in verband met de ten hoogste toelaarbare geluidsbelasting van de gevel van woningen eveneens de eenheidsgedachte in de formulering "tuinen en andere bij de woning behorende buitenruimten". ${ }^{38}$ Het betreft hier vanzelfsprekend regelingen, waraan zelfs de meest futuristisch ingestelde Romeinse jurist niet gedacht kan hebben. Maar de achterliggende conceptie van samenhang van huis en tuin is wezenlijk dezelfde.

\section{$\checkmark$ Tuinlieden}

De verzorging van de tuin was bij vermogende Romeinen, zo wordt wit vele in Rome, Tibur, Antium en andere platsen in Italië gevonden inscripties ${ }^{39}$ duidelijk, in handen van slaven en vrijgelatenen, die onder verscheidene aanduidingen in de bronnen voorkomen. De algemene aanduiding van wat wij ongeveer de tuinman zouden noemen is ropiariss ${ }^{40}$, een aan het Grieks ont-

35. Codex Theod. 9,45,4,pr = Codex llust. 1,12,3,pr. (anno 431).

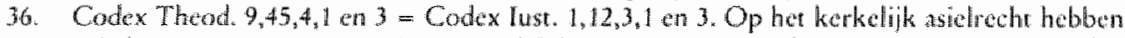
ankele (anno 5.11) vergeten', wermoedelijk wan Jastinianus afkomstige, constitutiones be-

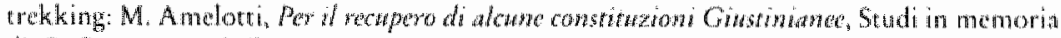
di G. Donaturi M Maan $1973, p, 25-32$.

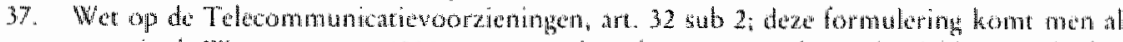
tegen in de Waterstatswet 1900, war woor het platsen van paten on het lowen wan dradion onder de grond da gedoogplich werelihe wordt opgeheven (Watersatswer art. 105 sub 2 ).

38. Besluir Grenswarden binner zones langs wegen, KB 20 nowember 1981, 9. 1981,688, art.

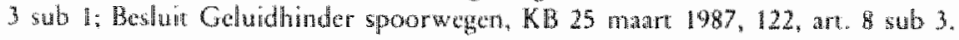

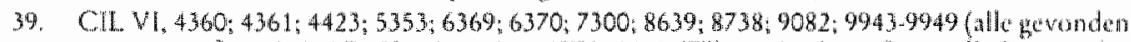

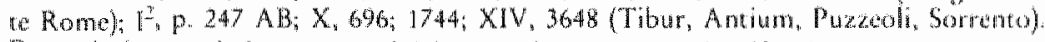

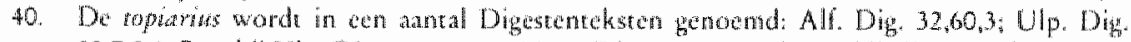
$33,7,8,1 ;$ Pap. bij Ulp. Dig. 33,7,12,42; Marc. Dig 33,7,17,2. Voomts bij Ciecro, Ad Qumew

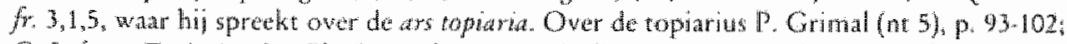

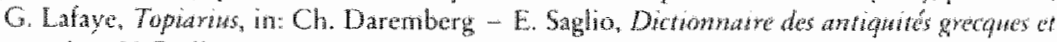
romaines $V$, Pariis 1919 p. $358-360$. 
leend woord dat al sedert de late Republiek in inscripties te vinden is en dat toch in eerste instantie voor de beoefenaar van de ars topiaria, voor de verzor. ger van een siertuin wordt gebruikt. Daarnaast burgeren nog andere woorden in, die samenhangen met de soort van de tuinen warin de betrokkenen hun dagelikse werk verrichten: de Bjolktor", die in een bij ons niet meer gangbaar talgebruik warmoezier - d.w.z. teler en verkoper van groente - heette; de olivitor, de olijgaardenier; de vinitor, de winngaardenier; de arborator ${ }^{42}$, de boomkweker. Vanaf de tweede eew kome de algemene anduiding bortwlan $\mathrm{s}^{43}$ voor tuinman in 2 wang. Uit literaire bronnen blijkt ook duidelijk dat het bij deze functionarissen altijd om slaven of om vrijgelatenen gaat. Cicero maakt melding van enkele holitores met Griekse namen, die een lapje van zijn tuin in Tusculum willen huren; vermoedelijk waren dit vriggelatenen. ${ }^{44}$ Plinius weet te vertellen over een rondgevormde appel die de Sceptiana werd genoemd nar de vrïigelatene die hem gek weekt had. ${ }^{45}$ En de beroemde kweker en gardenier met grote reputatie Antonius Castor, mogelijk een vrijgelatene van M. Antonius of een van diens kinderen, bereikte in de dagen van Plinius de 100.jarige leefrijd. ${ }^{46}$

In de juridische bronnen komt men evenzeer tuinlieden tegen, ook hier altijd in de hoedanigheid van slaven of vrijgelacenen, of in de late keizertijd (539) als dwangarbeiders in gewallen warin het gaat om leeglopers die sterk van lijif en leden zijn en aan het werk worden gezet. ${ }^{47}$ Papinianus behandelt cen geval, warin de vader zijn testament heeft gemaakt; hij lata an zijn dochter bij legaat zijn tuin na met alles wat daarbij hoort (bortus instructus), in het bijzonder ook de tuinslaven. Enige tijd na het maken van zijn uiterste wil schenkt hij aan zijn echtgenote enkele van deze tuinslaven, die vermoedelijk als gevolg daarwan an hun buitenarbeid op he: landgoed wan de man worden

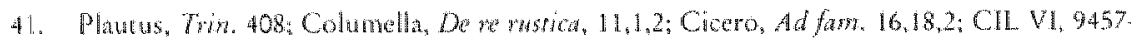

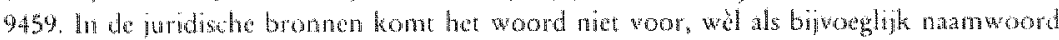

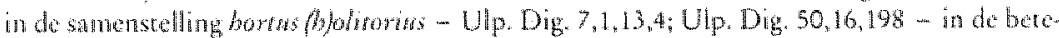
kenis van wat wils nowstuin zouden anduiden.

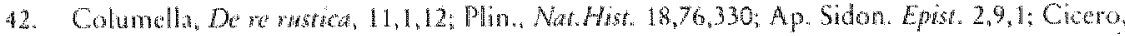

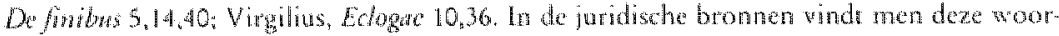
den niet.

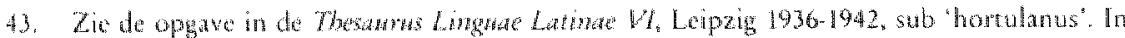

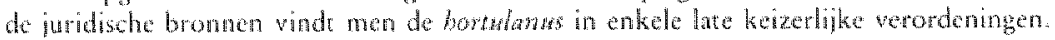

4. Cickro, Afl fawi $16,38,2$

45. Plin., Nedtitis. $15,15,50$.

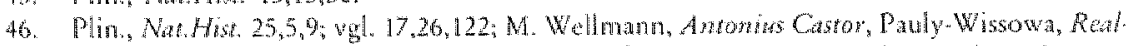

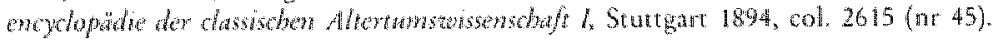

12 43. Nav. 80, ap. 5, pr. 
ontrokken. Na zijn dood clame de dochter op grond wan de making ook de tuinslaven onder aanvoering van het argument dat haar vader de schenking in zijn testament net bekrachtigd heet. Wie staat sterker: de dochter of haar moeder? Papinamus geeft als zin mening dat de latere wil van de vader, zoals deze kenbaar was in de schenlking van de slaven, sterker is dan de eerdere willswiting, neergelegd in her testament. ${ }^{48}$ De slaven blijwen derhalve bij de moeder, angezien door de verveemding het legaat als herroepen mag worden beschouxd, los van de vraag of hier van een verboden - en dus nietige - schenking wussen echtgenoten sprake was. De schenking was op zichzelf een symptoom van zijn voluntas mutata: nu de erflater zijn wil zo duidelijk had gewijzigd, was de erfgenam niets ann de dochter verschuldigd. ${ }^{\text {ty }}$

De docheer had overigens nog een geheel ander argument kunnen aanvoeren, zij het onder de omstandigheden wan dit geval dan eveneens zonder succes. Zij had zich op her standpunt kunnen stellen dat de tuinslaven eigenlijk bij de tuin hoorden. Papinianus spreekt zich daarover expliciet uit blijkens een aanhaling bij zijn tijdgenoot Ulpianus: bij het legat van een huis met alle goederen en rechten die daarbij horen - omma quae in domo smt - horen bijwoorbeld niet ambachtslieden die ook elders inzetbaar zijn, maar wèl slaven als portiers, kamerverzorgers, waterdragers en tuinlieden. ${ }^{50}$ Hetzelfde geldt bij her legat van het instrumentum fundi, d.w.z. het legat van alle roerende zaken - bezielde en onbezielde - die dienen ter bewaring, bewerking en het economisch op peil houden van een perceel landbouwgrond, bosgrond, weidegrond, een jachtrevier of wan een tuin. Afhankelijk van de functie van her betrokken percel, kan dit instrumentum - dus werktuigen, gereedschappen, voorraden, trek- en lastdieren, slaven - van karakter en samenstelling verschillen. Ulpianus nu stelt vast dat tot het instrumentum fundi in ieder geval slaven als boswachters en tuinlieden behoren. ${ }^{51}$ Elders relariveert hij dit standpunt door mede te delen dat de omvang wan het instrumentum per streek kan verschillen en dat her kan voorkomen dat ingeval op een goed onderhowden landgoed een siertuin aanwezig is, de tumleden onder het legat van het

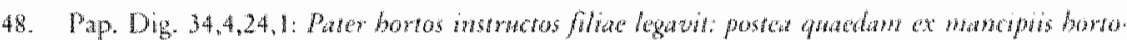

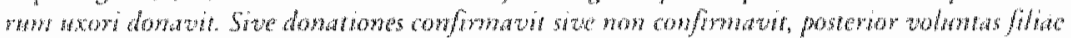

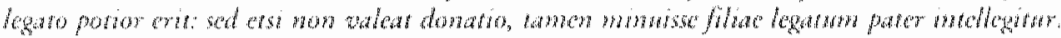
Fen anabog standpun is e vinden in Pap. Dig. 33,7,3,1.

49. Senev. Dig. $33,7,7,7$ in line.

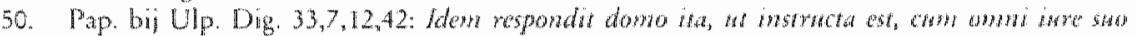

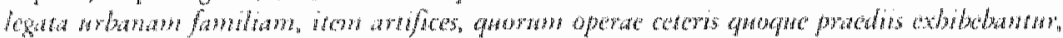

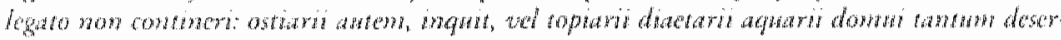

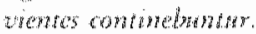

51. Ulp. Dig. $33,7,17,2$. 
instrumentum vallen. ${ }^{52}$ Ook de jurist Paulus wijst op het bestaan van regionat le verschillen bij de uitleg van wat wel en wat niet onder dit begrip valt. ${ }^{53}$ En niet alleen bestond er in de geografisch zo verspreide landen binnen het Romeinse rijk een uiteenlopende praktijk, ook historisch valt met betrekking tot de horigheid van tuinslaven an hun tuinpercelen nog een ontwikkelingsproces waar te nemen. Alfenus Varus, een lat-Republikeinse jurist, in wiens Digesta veelvuldig de meningen van zinn leermeester Servius Sulpicius Rufus worden geciteerd, neemt in diems voetspoor nog een afwijzend standpunt in: onder en generiek legat van 'alles wat voor het bebouwen van een perceel is gekocht' en aangeschaft' (omnia quae praedionum colendorum causa empta pa. rataque sumt), waarbij het er in de eerste plats gat om het vermaakte perceel grond economisch goed en blijvend an zijn bestemming te laten voldoen, valt niet de toplatius. De tuinman is er slechts, zo zegt hï, omandi cawsa, omwille van de wersiering van de tuin en niet ter vermeerdering van de opbrengst van de grond. ${ }^{54}$ In de late Republiek lijkt de twee eeuwen later anwijsbare binding van de hoveniers aan de door hen verzorgde ruin derhalve nog niet aanwezig re zijn.

De vrag of de tuinlieden al dan niet onder het legat vielen, hing samen met de grotere waarde die deze ambachtslieden in het algemeen voor hun meesters hadden. Ook beschouwde de topiarus zelf zich als behorende tot een hogere $k_{\text {a }}$ asse. ${ }^{55}$ Dit gewoel van eigenwaarde werd mede bepaald door de hoge eisen die werden gesteld aan hun kennis van bloemen en planten, hun inzichten in het begeleiden en bijsturen var het groeiproces en hun technische ervaring in het onderhouden van de valk uitgestrekte tumen en parken, kennis en ervaring die van generatie op generatie werden doorgegeven. ${ }^{56}$ Wie zich de moeite getroost het tiende boek van Columella"s De re rustica te lezen, waar de cultus bortorm in al zijn facetten op elegante wijze in diclatvorm wordt bezongen, komt tot de overtuiging dat veel van de antieke bortularit, topiarit en hoe zij verder ook aangeduid mogen worden tenminste de evenknie waren van onze hedendagse in het middelbar en hoger landbouwon-

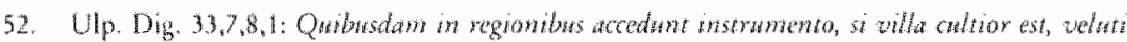

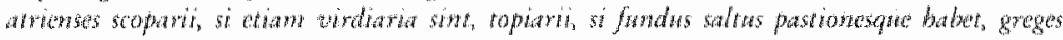
provown pastores saliwari.

5.. Paul. Digi, $33,7,18,3$ in fine.

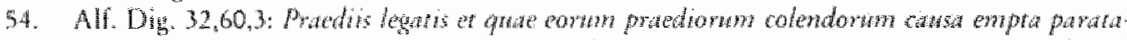

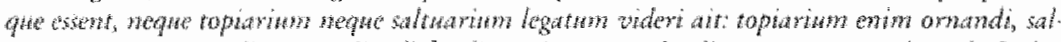

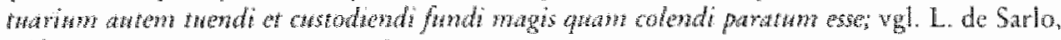

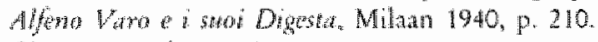

55. Ciccro, Paradona storimom 5,36 .

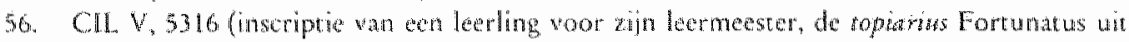
Comos. 
derwijs opgeleide hoveniers en tuinarchitecten, ook al was hun sociale plaats in de Romeinse samenleving zoals die van alle ambachtslieden een tamelijk geringe. 57

Nog eenmaal, helaas in een negatief beeld, duiken tuinlieden in de antieke rechtsbronnen op. In 538 wardigt Justinianus een lange corstitutio uit om een einde te maken aan de malafide prakrijken warover door eigenaren in Constantinopel die hun land voor uninbouw verpachten, bij herhaling geklaagd is. De bortwani zijn, als gevolg van de trend naar corporatieve bindingen in de vierde en vijfde eeuw werenigd in een 'gilde', het collegim hortwanorum. In anmerking genomer dat in de oudheid de overheid in het algemeen weinig bereidhetd toonde om klachien uit de burgerij serieus te nemen of gehoor te geven aan petities van belangengroeperingen, moeten de tuinlieden hun corporatieve macht wel bijzonder misbruikt hebben, dat het zover kwam dat de keizer aan de stadsprefect Longinus bevel gaf om orde op zaken te stellen. Op levendige wijze en minder geormamenteerd dan de literaire stijl van de zesde-eeuwse kanselarij-juristen zich in andere Novellae soms manifesteert, worden in de desbetreffende constitutio de kwalijke praktrijken van de zich on gegeneerd bevoordelende bortwlami uit de doeken gedaan. Bij het aangaan en beëindigen van een pachtovereenkomst werden vanuit het collegium bortwla nomm uit eigen kring taxateurs benoend om de verrekening tussen eigenaar en pachter vast te stellen. Bij het aangaan van de pacht werd de voorhanden zijinde beplanting laag getaxeerd, zodau de pachter daarvoor slechts een klein bedrag an de verpachter behoefde te betalen. Na afloop van de pachtrermijn weranderde dit in zijn tegendeel: de aangewezen taxateurs - derhalve collega"s wan de pachters! - joegen hun waardering voor de aanwezige beplanting drastisch op en lieten de eigenaar soms thet zesvoudige of meer van de werkelijke warde aan de vertrekkende pachter betallen, waarbij het argument dat er bemest was, de prijs nog verder kon opdrijven. De taxateurs werden met de dag hebzuchtiger, omdat zij wisten dat zij straks bij het beëindigen van hun eigen pachtovereenkomst ók flink zouden kunnen incasseren. Bij een tweede, derde en volgende pachtrelatie kon zich deze praktijk herhalen, met als gevolg dat de eigenaar geleidelik tot de bedelstaf werd gebracht.

Justinianus droeg de stadsprefect van de regio Constantinopel op een einde te maken aan deze prakrikken. De vwin dient door de eigenaar van zijn pach.

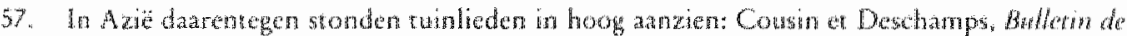

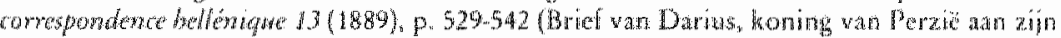

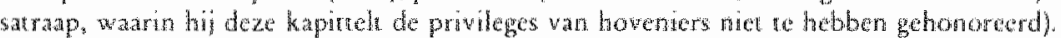

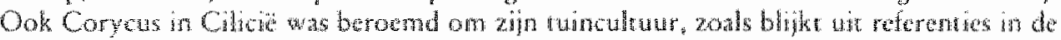

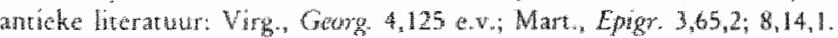


ter te worden terugverkiegen in de state warin hij hem had afgegeven; taxaties dienden op beide momenten wolgens dezelfde norm en op grondstag van de werkelijke warde plats te vinden. Kortom: eenheid van procedure bij aanvang en beëindiging wan de pachtovereenkomst moest de eigenaar. verpachter regen de hebzucht van de mer elkar samenspannende bortulani beschermen.5 5

Het matschappelifke perspectief voor de bortulani als blijkend uit de Romeinse bronnen, is vooral in de jongste tijd met grote snelheid veranderd. Maar echte beschermende regelingen, recentelijk gepard gaande met het wettelijk verankeren van verhoogde kwaliteitseisen, zijn pas na de Tweede Wereldoorlog opgekomen; voor het eerst in de Wet economische mededin. ging, war het beroep van tuin- en landschapsarchitect wordt aangewezen als cen vrij beroep in de zin van de wet. ${ }^{59}$ Voor het middelbaar en hoger land bouwonderwijs zijn tamelijk omstandig wettelijke voorschriften tot stand gekomen, krachtens welke degenen die het ontwerpen, aanleggen en onderhouden van tuinen tot hun professie beogen te maken, met vrij gedetailleerde $k$ waliteitseisen worden geconfronteerd. ${ }^{60}$ De geleidelijke upgrading van het beroep van tuin-en landschapsarchitect vond zijn sluitstuk in een sedert lang noodzakelijke en, gezien de gestelde wettelijke beroepsvereisten, gerechtvardigde beschermende wetgeving: in de Wet op de architectentitel $1987^{61}$ heeft, mede ter uitvoering van de richthin van 10 juni 1985 van de Raad van de Europese Gemeenschappen, de titel 'tuinarchitect' woor o.a. diegenen die mer goed gevolg het doctoraal examen in de studierichting der landschapsarchitectuur aan de Landbou w universiteit te Wageningen hebben afgelegd, en die zijn ingeschreven in het Register wan tuin- en landschapsarchitectuur, een wettelijke bescherming gekregen. 62

58. Wowelle 64 verkorte Latijnse wersie in de Epitome Luliani 58 . V. A.H.M. Jones, History

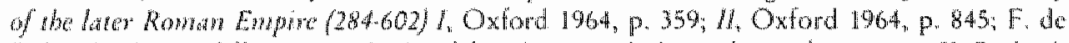

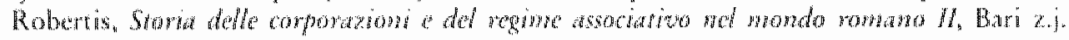
[1971], P. 215 an 3.

54. Wet Economisclue Meddedinging 1956, art 1a

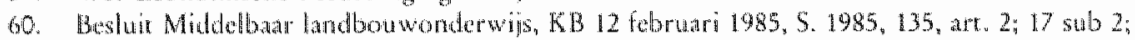

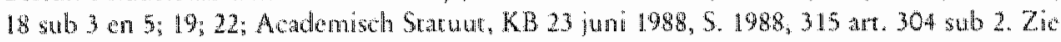

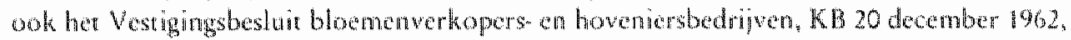

5. 1962,548 , art 12 sub a, ba $\mathrm{a}$.

61. S. 1987,347 .

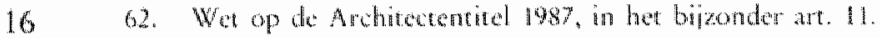




\section{De twin als object van legaat en futeromanis}

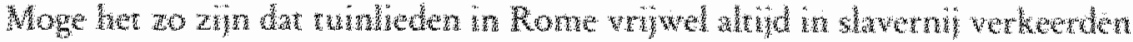

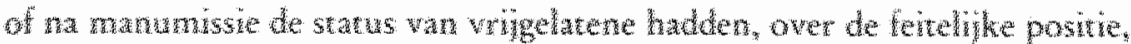

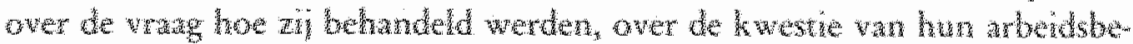

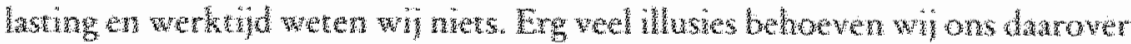

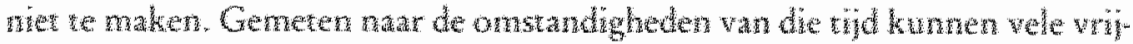

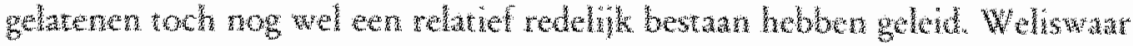

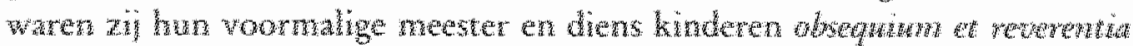

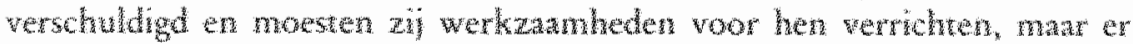

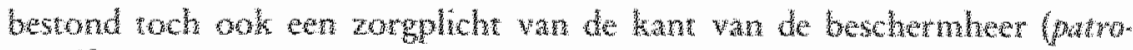

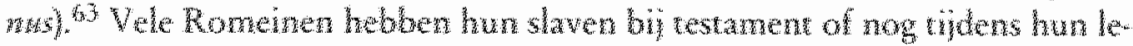

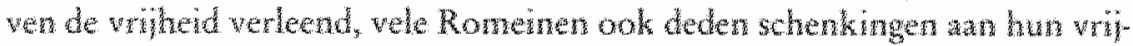

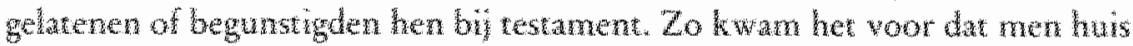

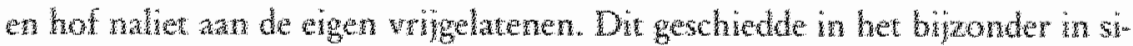

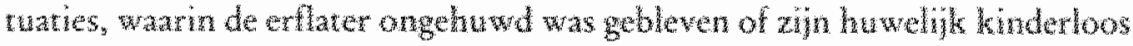

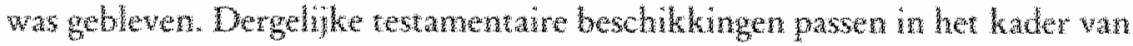

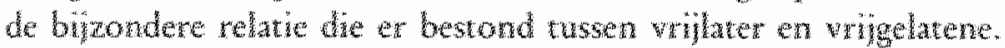

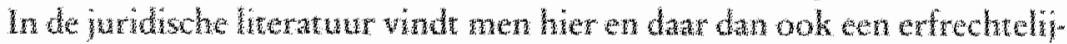

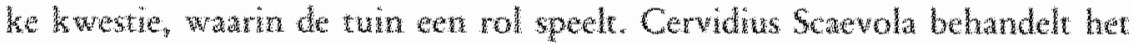

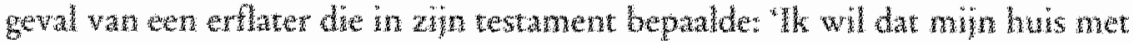

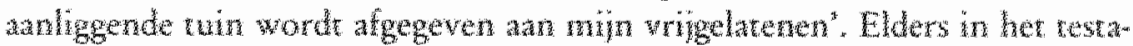
mert was, in strid met deze dudelike amwinzing, een clausule opgenonen ten guthste wan de wh minn vrigelatenen heb gegeven, door min ertgenam her door mil bewoonde

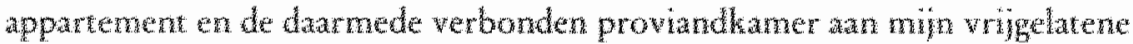

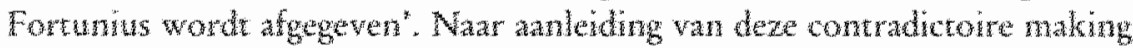
was de vraag opgeworpen of het ideicommis - want dat is het, en nier een legaat, zoals de tekst van de making suggereert - door de erfgenaan moest worden uitgevoerd. Deze stelle zich op het standpunt dat de erflater bij fidecommis zijn huis en tuin aan al zijn vüigelatenen had gegeven en dat deze wilsbeschikking voorrang diende te hebben boven her fideicommis ten gunste van Fortunius. Scaevola steurde de erfgenaam in deze stellingrname. ${ }^{64}$

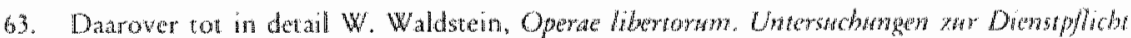
fretgelassemer 5klaven, WiesbadenSutitgart 1986.

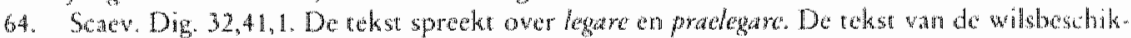

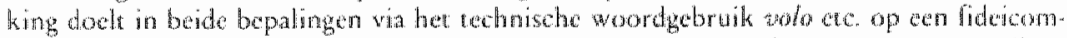

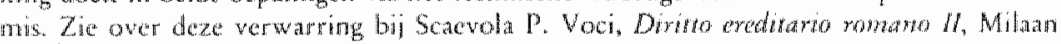
$196,3^{4}$, pag. 234 noot 45 
Naast dit soort genereuze bevoordelingen komen we ook begunstigingen van geringere omvang tegen. Zo kwam het ook voor dat men de opbrengst. wan een moestuin, die men woor een beperkte wijd gepacht had, bij legaat of fideicommis vermakke. Labeo beschreef een dergelijk geval in zijn Nagelaten oeuvre, dat door lavolenus later werd bewerkt. ${ }^{65}$ lemand die van de overheid een lapje grond had gepacht voor eenvoudige tuinbouw, had voor de duur van de resterende pachttermijn - deze was meestal vijf jaar - de opbrengsten gelegateerd aan een zekere Aufidius. Om te voorkomen dat zijn laatste wilsbeschikking door enigerlei vormfout nict tot uitwoering zou komen, nam hij in zijn testament een tweetal formele legaten op, een legatum per dawnationem en cen legatum sinendi modo: "Heres meus damas esto dare conductionem eorum bortorum', 'mijn erfgenaam zal verplicht zijn de pacht van die tuinen aan Aufidius te geven", en 'Heres mews darmas est sinere Aufidium eos bortos uti et frui", "mijn erfgenaam zal verplicht zijn toe te laten dat Aufidius deze tuinen gebruikt en ar de opbrengst wan geniet". Zozeer wenste de erflater zijn uiterste wilsbeschikking uitgevoerd te zien dat hij twee legaten opnam voor hetzelfde doel: Aufidius te bevrijden van het betalem van pacht allsmede hem de revenuen te doen houden. Daartoe was het legatum sinendo modo, dat immers tegelijk bevrijding van het betalen van de resterende pachtsom inhield, voldoende geweest. ${ }^{66}$ Het damnatielegaat met zijn generale werking is als een extra zekerheid opgenomen, een praktijk die ook na het op gelijkschakeling der legaten gerichte senatusconsultum Neronianum ${ }^{67}$ nog veelvuldig is voorgekomen. Aan het legaat ten behoeve van Aufidius worde dan ook de ruimst mogelijke uitleg gegeven: bevrijding wan betaling van de resterende pachtsom alsmede het recht de opbrengsten tot het einde van de pachttermijn te genieten. $^{68}$

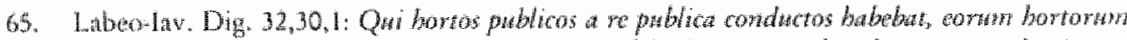

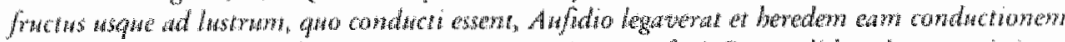

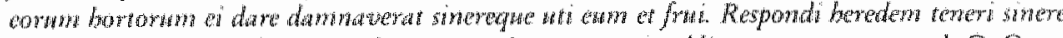

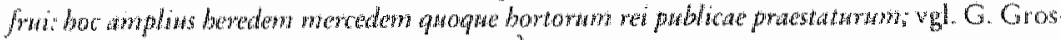

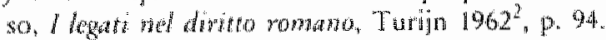

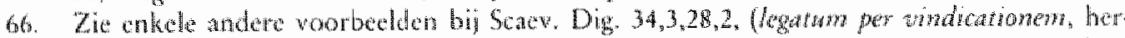

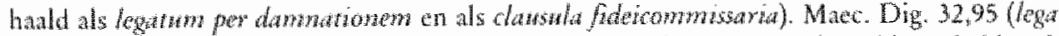

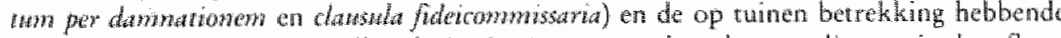

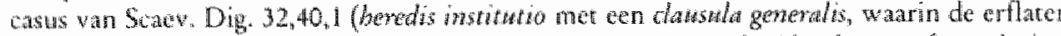

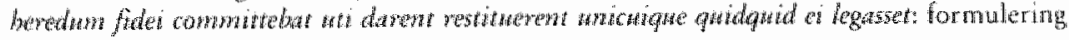
ex Scaev. Digis. $3,4,3,28,2$ ).

67. Vgl. Iaul Dig. $34,3,16$.

68. Herover Kaser (nt 31), p. 745-746. 


\section{Erfrechtelijee interpretatieproblemen}

Zowel de bijna uitzinnige casuistiek in de Digesten als vele honderden inscripties leggen nog getuigenis af van het grote belang dat de gemiddelde Romein aan het maken van een testament hechtre. Daarin kwam her tot gedetalleerde wilsbeschikkingen, zeker in de gevallen dat er enig vermogen anwezig was. Daarvan profiteerden niet alleen de naaste familieleden, maar ook vrienden, vriggelatenen, slaven en veelvuldig ook overheidspersonen, bijv. de keizer, of publieke organen, bijw. de gemeente warin men woonachig was geweest. Onder deze legaten en fideicommissen die men, na het tijdelijke met het eeuwige verwisseld te hebben, gaarne tot uitvoering zag komen, bevonden er zich ook vele die tuinen tot object hadden. Zo had de blijspeldichter Terentius in de tweede eeuw v. Chr. al twintig ingera an tuinen aan de Via Appia, gelegen in de bunrt van de tempel van Mars; hij liet deze gronden bij legaat na aan zijn dochter. ${ }^{69}$ Meestal zal er bij de uitkering van deze makingen geen probleem zijn geweest; maar vaak deden zich natuurlijk ook interpretatiekwesties voor. Vallen bijv. onder een legatum penus urbana, het legaat van alle levensmiddelen, voedsel en drank die men in de stad heeft, ook de voorraden die zich buiten Rome in de tegen de stad aan liggende tuinen bevinden? Ja, zegr Paulus. ${ }^{70}$ Zo was er naar Romeins recht geen bezwaar om bij legatum per damnationem over de zaak van een ander te beschikken. De erfgenaam diende dan zijn uiterste best te doen een dergelijke zaak wan de betrokken eigenaar te kopen en na verkrijging aan de legataris uit te keren. Lukte dit niet, dan kon de vervangende waarde in geld worden betaald. ${ }^{71}$ Toch hadden dergelijke makingen ook hun grens: vermakte men bijvoorbeeld de Horti Sal. lustiani, een door de schrijver Sallustius na 46 v. Chr. aangelegd omvangrijk tuinencomplex dat honderd jaar later, vanaf keizer Nero tot nawijsbaar in de vierde eeuw, aan de Romeinse keizers toebehoorde, dan werd men geacht krankzinnig te zijn ${ }^{72}$, angezien het hier om zaken extra commercim ging,

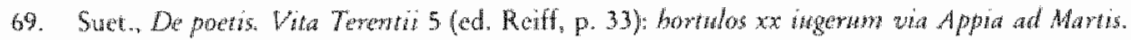

70. Paul. Dig. 33,9,4,5; vgl. Voci II (nt 64) p. $286 \mathrm{mt} 70$.

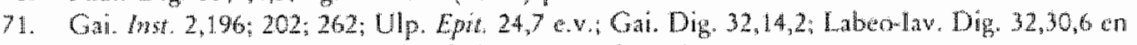
$35,2,61 ;$ Ulp. Dig $30,71,3$; detalls bil Kaser I (nt 31), p. 749 .

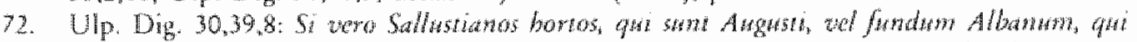

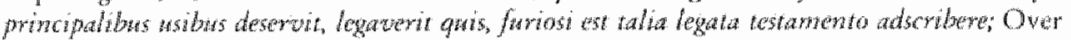

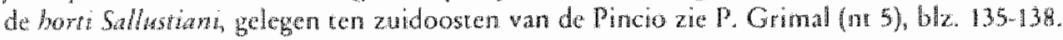


zaken warvan het aan jeder zimnig mens bekend was dat zii geen voorwerp wan dit soort beschikkingen konden zijn.

Verschillende interpretatick westies hebben betrekking op de hortus instractsus, de tuin met toebehoren. Wat valt wel en wat niet onder dit toebehow ren? Valken bijvoorbeeld ook de wijnen eronder die de eigenaar daar in voorratad heeft om er prettiger te kunnen verblijwen en gasten te ontvangen. In dit geval wel, zege Ulpianus, die dit naturlijk een grensgeval acht; men kan er averigens over wisten of amphoren wijn nu werkelijk zo sterk deel uitmaken wan een bortus instructus dat zij onder het legaat vallen, zelfs wanneer het gaal om een op aangenaam verpozen gerichte lusthof. Is de tuin alleen maar gebruikt als een bevoorradings- of opslagplaats, dan vallen de daar gebrachte zathen er niet onder. ${ }^{7 / 3}$ Mar betreft het een fideicommis van een huis mer het erbil behorende huisraad dat de erflater, met het oog op ziin vertrek naar de provincie die hij als gouverneur zou gaan besturen, naar zijn tuinen had gebracht om het daar veilig op te slaan, dan kan dit door de begunstigde natuurlijk wèl met succes worden opgeëist. ${ }^{74}$ Onder het legaat van een bortus in structus vallen volgens Papinianus en Ulpianus echter niet de "zilveren voorwerpen voor typisch vrouwelijk gebruik", zelfs al was dat zilver daar aanwezig

Aan dit zich uitbreidende tuinencomplex waren vaste cuinslawen werbonden, zoals inscrip

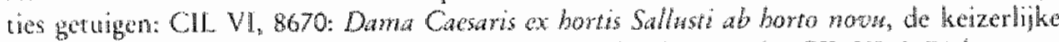
shaf Dama, van de cumen var Sallustiss, belast met de neuwe tuin; CIL VI, 867 (arts ver-

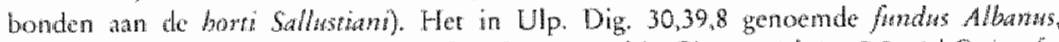

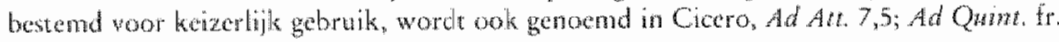
$5,13,10$.

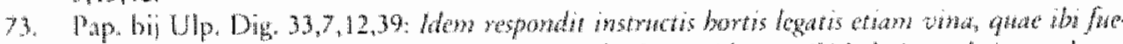

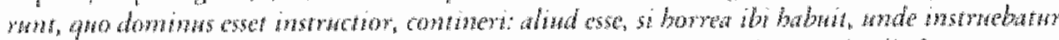

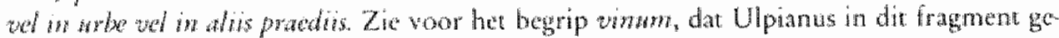
brukt, zijn extensieve interpretate in Dig. 3,6,9,pr; hierbij Voci II (nt 64), p. 287.

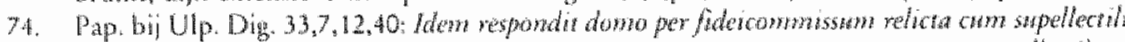

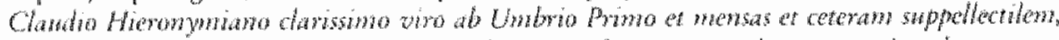

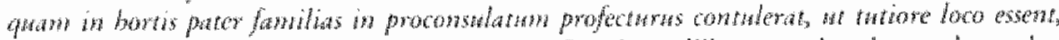

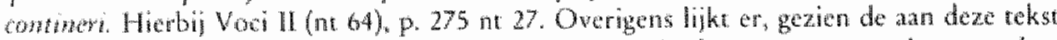
wornfgande passage, weel woor te pleiten on bortis in dir fragmenta cemenderen tot hor res; juridisch-inhoudelik blift he advies van Papinanus dan onerigens ongewizigd. Chadins Hicrongmianus, an wio Papinianus zijn advies uitbracht, is mogelijk dezelfde als de gowverneur wan Cappadocie, L. Claudiws Heronymianus; over hem berthe Terthianus, Ad $\$$ atp. 3 , dat hij, ondanks het feit dat hij en christenlater was, woh bigna in het whisteligk

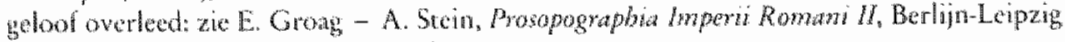
1936 (herdruk 1958), p. 206 (m 888). 
om de tuin en het daarin gelegen woonverblijf beter aan zijn bestemming te doen beantwoorden ${ }^{75}$; de speciale beschikking met betrekking tot het zilver gaat boven het generieke legat van de toegeruste tuin.

\section{De tuin als object van schenking}

Juridische en epigrafische bronnen ${ }^{76}$ vermelden derbalve met een zekere frequentie de tuin als object van erfrechtelinke bevoordelingen. De juristen hebben geen enkele moeite met het vermaken wan tuinen en leggen steeds een accent op exegetische vragstellingen rondom dit soort beschikkingen. Overgang van tuinen en parken krachrens erfstelling, legaat of fideicommis werd als gewoon beschouwd in de samenleving niet in de latste plats ondat het veelal om bloemen- of moestuinen ging. De revenuen van deze percelen kon den door de eigenaar via de locale marki te gelde worden gemakt. ${ }^{77}$ Veel minder horen wij over vrijgevigheid bij leven van de tuineigenar. ${ }^{78}$ De juristen reppen hierover nergens, zodat de conclusie gerechrvaardigd lijkt dat schenking van tuinen, parken e.d. niet tot de orde van de dag zal hebben behoord. Wel is in de 17 e eeuw in Rome bij de Porta Labicana een inscriptie gevonden, warin onder een samenstel van voorwarden de materiële schen. king van een tuinencomplex is vastgelegd. ${ }^{79}$ Het gat in dit geval niet om een wetenschappelijke verhandeling, maar om een uit de dagelijkse praktijk wan de tweede of derde eeuw in Rome overgeleverde documentering wan hetgeen materied een schenkingshandeling was. Als schenker ontmoeten wij T. Flavjus Syntrophus, die de volgende akte het opstellen:

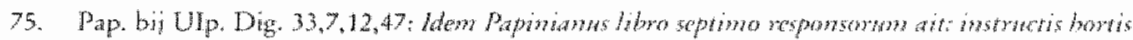

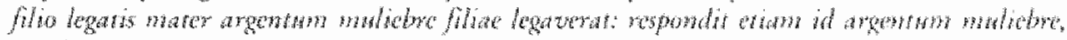

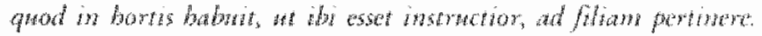

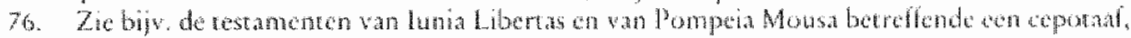

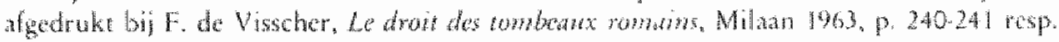
p. 199.200

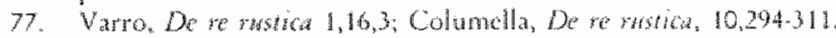

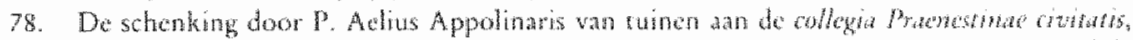

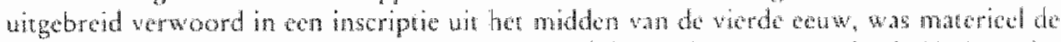

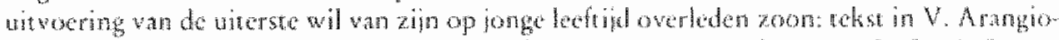

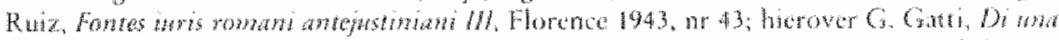

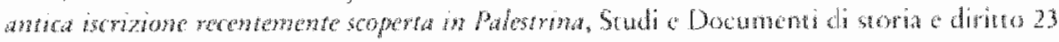
(1902), p.778s.

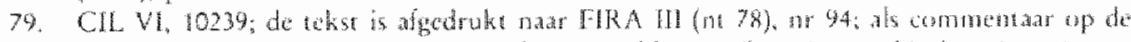

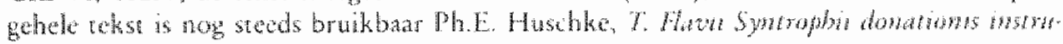

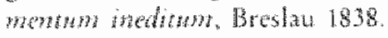


T. Flawius Symtraphus, priusquam hortulos Epagahianos Dads[chianos -ianosque]

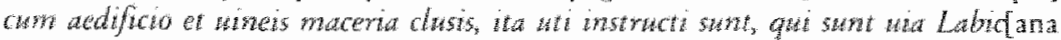

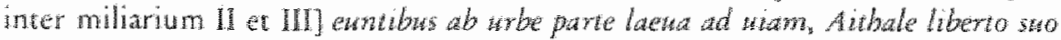
mancipio davet, tesi[atus est se in hanc condicionem mancipare, wi infra scriptum wat:

Si tibi hortos Epagathianos Dad(uchianos - iarosquel qu(ibus) d(e) aghtury qui) s(upra) s(cripti) s(unt), wnancipio dedero wachamoute possessionem tradidero, turn

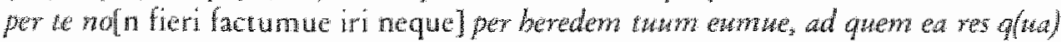
d(e) a(gitur) pertimet perindbot, quo minus it bo[rti aedificiumue sit com]mune tibi cum conlibertis twis utrusque sexus, qui at me testamento codicillisule honorati erunt, cunque is frularts, parique portione inter wos redium eiws custodiatis ita, at die parentali [meo, item XI K(al.) Apr(iles) die uiola]tronis, item XII k(al) Innias

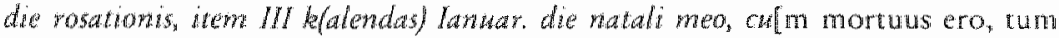
ut] guisque uestrum uinet, quine ex wobrs genti erunt, ant a gho westrum quis ma[numissus erit, ad quem unum] pluresue portio similiter butus loci aedificiue per. whebit, id ex formula stu[pra scripta diuidaris: et si quis/ ibi inbabitare wolterit, ex communi omnium consensa matorisue partis [eortum qui uiuent id el licear]: quate auten membra aedifici tuacabunt, in reditu sint ita, wh buic uolunta[ti parentes, deducta summa] impensate et quod ad tutelam aedific opus erit, quod reliquom erit, inter u[os diuidaus, er sic horti cum aedilficis instrumentoque omni, quod die morus mede ibi babuero, whin aestro [deseruiant quamdiu uivetis]: quine ex uobis nouissimus monetwr eodem modo testamento suo [cauear ut horri s(upra) s(cripti) per cos q(ui) s(upra) s(cripri) s(unt), quiue] ex iss prognati erint, aequaliter in familia $\langle\langle m\rangle>$ nominis mei permanea[nt eodemque semper iure sint. Et] ab bac re promissioneque dolus malus cuins westrum, de quibus agitur, a[bsit. Si aduersus ea f(actum) erit, $\mathrm{g}$ (uanti) e(a) r(es) e(rit), ] tantam pecuniam dan, et amplias poenae nomine (sestertium) L m(ilia) n(ummum) stipulatu[s est T. Flauius Syntrophus] spopondit T. Flasius Aitballes libertus.

Tum bortulos cum aedificio e[t uineis maceria clusis, ita ut] empti sunt, et quae postea is accesserumt, mancipio accepit T. Flauius A itbatles de T. Flauio Syntropho (sestertio) n(ummo) 1] libripende Ti. Claudio Phileto, antestartus est T. Flaumm Theopom[pum.

Et in uacuam possessionem horto]rum, $q$ (uil) s(upral) s(cripui) s(unt), ex catsa supra scripta ire aut mittere inssitit. T. Flanius $S_{y}$ [ntrophus T. Flauium Aithallem, seque] inde excessisse desissegne possidere $\langle<$ que $\rangle>d i x t_{\text {s }}$ salsa wolu[ntate si quat ossa deinceps supra dietis] bortis inferri consacrarize woluerit.

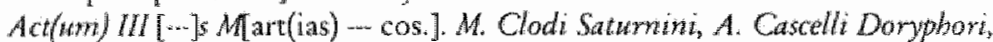
T. Flaui Pii, T. St - - T. Flaui Theopompi], Ti. Clandi Pbile[ri].

[1.] T. Flavius Syntrophus heeft zijn Epagathianse, Daduchiaanse en ...aanse cuintjes met gebouw en de wijngarden binnen de omheining, in de toestand waarin ze zich bevonden, door mancipatio overgedragen aan zijn vrijgelatene Aithales. De goederen ziin gelegen tussen de tweede en derde mijlsteen van de via Labicana, meteen aan de weg, voor wie uit de stad komt an de linkerkant. Vóón de mancipatio heeft hij verklaard dat daarop de volgende voorwarden van toepassing zijn.

[II.] Als ik u de onderhavige Epagathiaanse, Daduchiaanse en ...anse tuinen die hierboven aangeduid zipn, door mancipunio overdraag en u het ongestoord bezir 
verschaf, dan zullen u, uw efgenam of anderen an we de onderhavige goederen zullen roebehorey, nu en in de toekomst do wolgende bepalingen in ache nemen.

11.] De genoemde tuinen an het gebou zullen gemeenschapelik toebehonen an u en an uw mede-vrigelatenen wan beider geshach die dow mij bü testament of codicil vrigelaten zullen zin.

[2.] Met hen zult u de vruchten trekken en u zull de opbrengst bewaren om dico, wanner ik overteden ben, in galike portes ve verdelen op do Paremalia, op de viooltjesdag (22 mart), op de rozendag ( 21 mei) en op min verjardag (30 december).

[3.] De wadeling zal plaatsinden cussen degenen wan u die dan in leven zijn of uw nakomelingen, of degenen die door u vrijgelaten zijn. Aan diegene of diegenen zal evenzo een evenredig deel coebehoren van de grond an het bouw, volgens dezelfo verdedsleuril.

[4.I Indien iemand het geboum wenst te bewonen is dat coegestan als he ge bewn met instemming van aller of van de mectertheid van degenen die dan in leven zijn.

[5.] Indien ugehoor geef aan deze wens zullen de gedeelten van het gebouw die lecg zijn deel wimaken van de opbrengs, op zodanige wije da de opbrengs verminderd wordt met de algemene kosten en de kosten voor onderhoud van het gebouw. Het restant zult u onderling verdelen.

[6.] Zo zullen de tuinen met gebouwen en alle toebehoren die ik op de dag van mijn dood heb, w tor nut zin zolang als u leefr.

[7.] Wie van u als latste ower lijd, moer op dezelfde wize in zijn testanent beptlen dar de angeduide tuinen via de angeduide personen of via hum nakome. lingen op gelijke wijze met mijn familienam rerbonden blijern, steeds volgens dezelide bepalingen.

[8.] U allen die herbij berokken zijt, zult zich in uw toezeging in deza zak onthouden van bedrog.

[9.] Voor her geval dat in strijd word gehandeld met deze bepalingen heeft $\mathrm{T}$. Flavius Syntrophus vormelik bedongen dat er zoveel betaald zal worden als de schade groot zal ziin, en bovendien een bedrag wan 50.000 sestertien bij wijem van boete. Ziin vrigelatene T. Flavius Aithales heet di vormelik toegezegd.

[111.] Vervolgens heef. T. Flawus Aithales van T. Favius Syntrophus de tuintes met het gebouw en de wingarden binner de omening verkigen voor 1 sester. re, in de toestand watin zij zich bevonden ten rijde van de ankoop, met hetgeten ou later bigekomen is. Hif had als gevige medenomen T. Tavius Theopompus. Wegschanhouder was T. Claudius Philerus.

[V.] Op de angeduide grond heef T. Favins Symtrophus T. Favius A ithales opgedragen on zich in her ongestoord bezit te stellew wh de angeduide turnen. Hij heef verkland dat zij hem onvallen zijn en dat hij opgehouden heet he beziten, onder voorbehoud wan de mogelikheid dat zijn beenderen in de angeduda winen worden begraven en gewij.

[V.] Opgenaakt op ... maant, onder het consulat wan ..., in het bijzin van $M$. Clodus Saturninus, A. Cascellius Doryphorus, T. Flavius Phus, T. St..., T. Faw ens Theopompun, T. Chadius Philetus. 


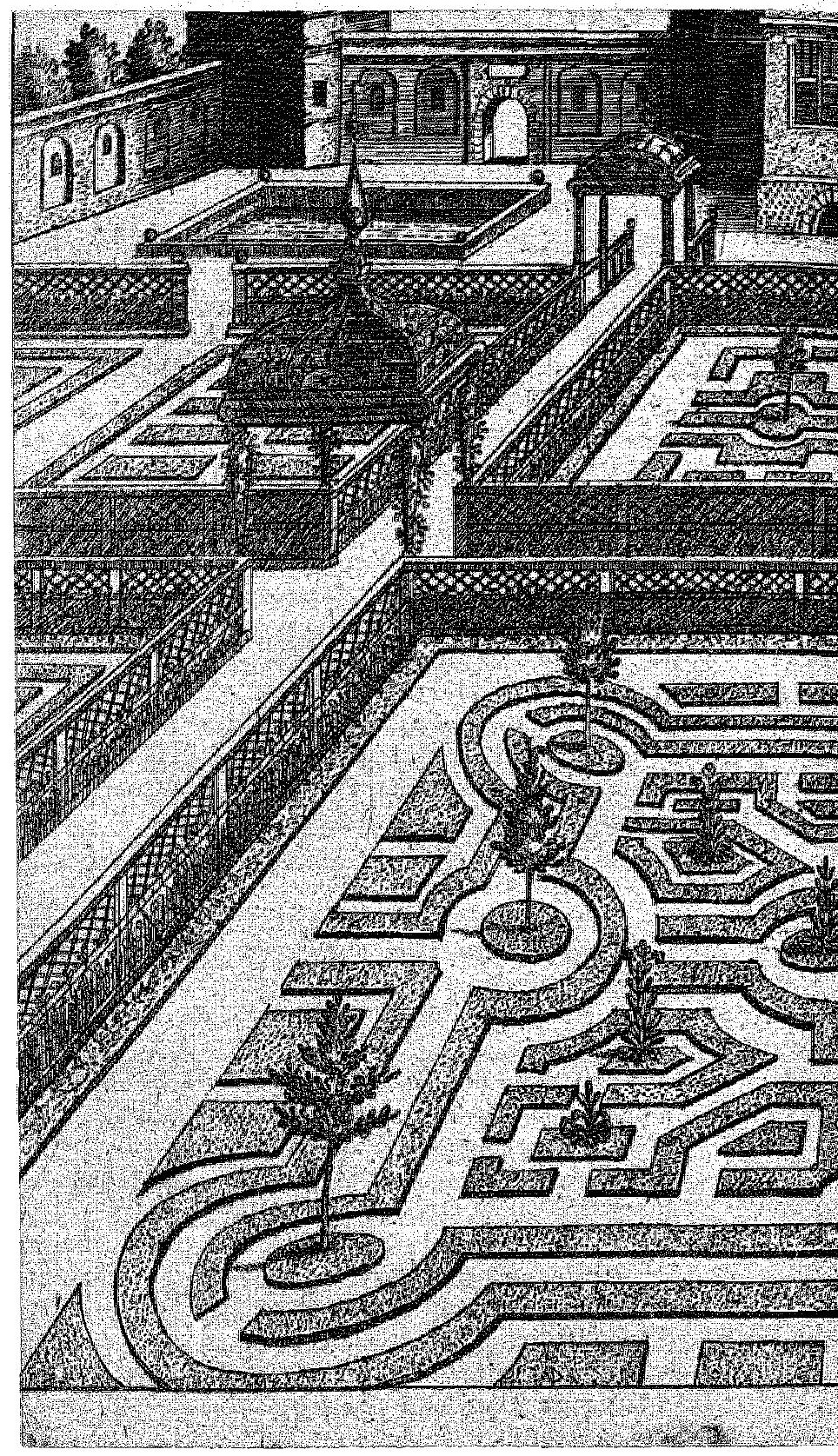

Ambulationes en gestationes in een architectonische tuin naar de door Vitruvius geinspireerde renaissancevisie van Hans Vredeman de Vries (1525 ca. 1605). 


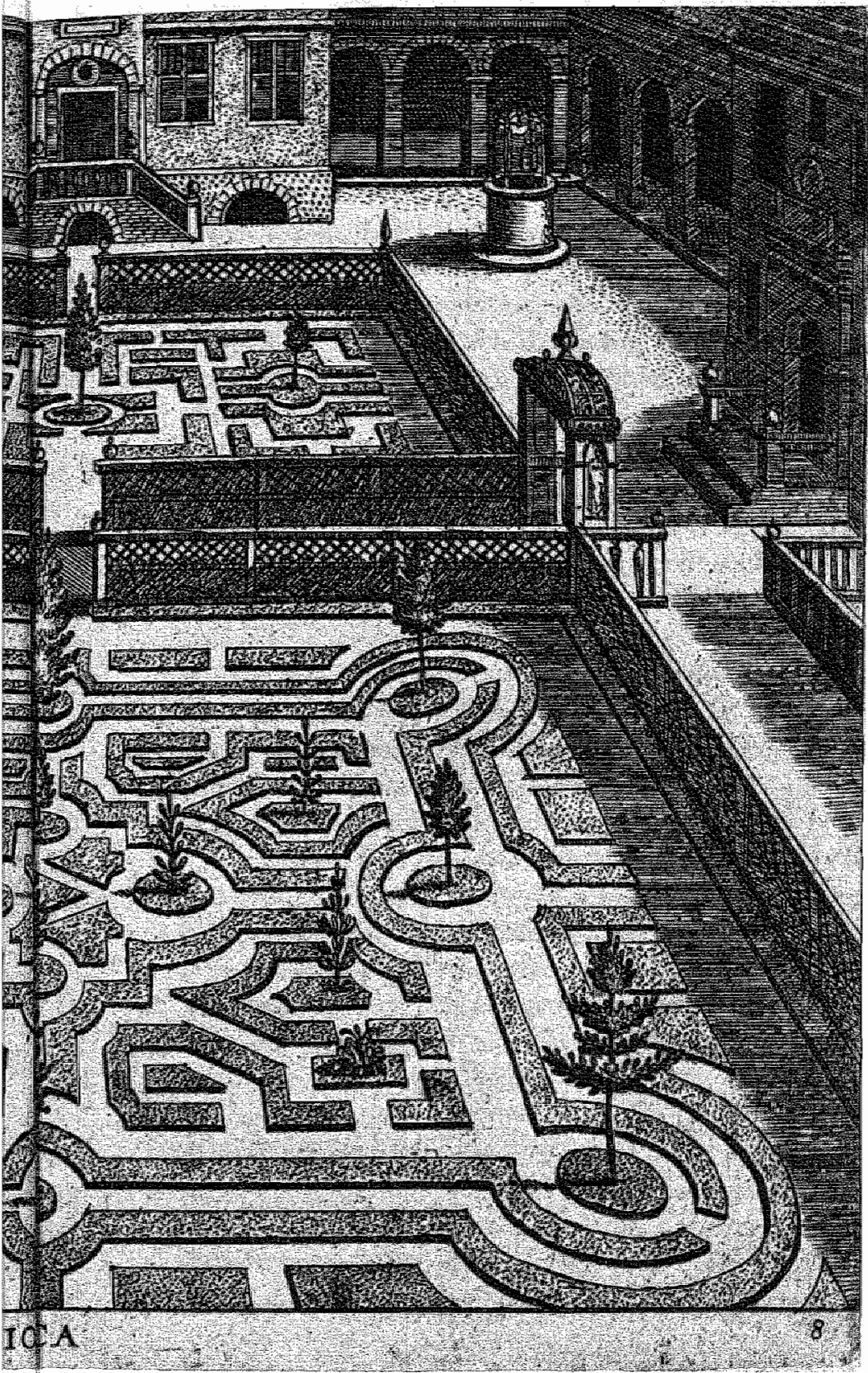


De akte sprekt inhoudelik voor zichzelf, maar vragt op enkele plaatsen toch om nader commentaar. Syntrophus, overigens gezien zijn nam een vrijgelatene, gedraagt zich typisch als ten Romein. Ten einde zijn nagedachtenis levend te houden, draggt hij zijn tuintjes (bortul) in de directe nabijheid van Rome om niet over door een vormelijke leveringshandeling (mancipatio) aan zijn wrijgelarene Aithales, onder de gehoudenheid na zijn dood een aantal per. sonen die tijdens het opstellen van de akte nog in slavernij bij hem verkeerden daarin te laten delen. Wellicht is hij ongehuwd; in ieder geval heef hij geen kinderen. Erggroots komt Syntrophus in ieder geval niet over, niet alleen niet wegens de egocentrische voorwaarden waronder de overdracht platsvindt, mar ook omdat het crnaar uitziet dat hij wel gedwongen moet zijn geweest Airhales met het oog op deze transactie eerst wrij te laten, bijv. door manumes. sio windicta. Alle andere begunstigden bliyen tijdens zijn leven in slavernij en slcchts degenen die hij bij testament of codicil in wrijheid zal stellen, zullen na zijn dood van zijn vrijgevigheïd kunnen genieten. Neemt men aan dat alle slaven wan de vrijgevigheid en de intenties van hun dominus geweten hebben, zouden zij dan misschien nog harder voor hem hebben gezwoegd?

En Aithales? Als vrijgelatene had hij geen sterke positie: Syntrophus kon altijd zijn wil veranderen en de schenking ongedaan maken op grond van zijn patronaatsrecht, 80 Verradt niet onk de acte zelf onbedoeld deze achterliggende mogelijkheid, war geschreven is" 'de tuinen, gebouwen en alle toebehoren die ik (1) op de dag van mijn dood heb' (II, 6). De pressie op Aithales en de nog in slavernij verkerende woorwaardelijk begunstigden om het beste beentje voor te zetten moet groot geweest zijn.

Het gaat om hortuli met cen opstal die als woning diende alsmede met omheinde wijngarden, derhalve om wat wij moestuinen zouden noemen en niet om architectonische siertuinen. De oorkonde spreekt bovendien ower revenuen van het land; daarmede is de siertuin dus uitgesloten. Het eerste problcem van praktische aard dat zich voordeed, was het opnemen van een goede beschrijving van de ligging van de tuinen (sub 1). Een kadaster was er in Rome nict, zodat veel afhing van cen goede omschrijving van de situatie. De juristen hebber in hun werken aan deze problemwtiek ook aandacht geschonken, angezien het voor de leveringsplicht wit hoofde van koop, schenking of een andere ritel, ondubbelzinnig diende vast te staan welke percelen geleverd moesten worden. Objectieve ruimelijke anwijsbatheid was vereist, wilde men problemen bij de levering, de in bezit neming, de verjaring of het nader- 
hand vestigen van beperkte zakelike rechten op het perceel voorkomen. ${ }^{81}$ In de aanhef is de ligging dan ook zorgvuldig en exact gederermineerd; ook wordt gesproken van omheinde gronden ${ }^{82}$ en bortuli, dus typische tuinpercelen. Aangegeven wordt voorts dat Syntrophus vór (priwsquam) de overdracht door mancipatio in vormelijke bewoordingen heeft aangegeven onder welke voorwaarden de scherking plaats vindt 83 Dit is de numcupatio, die vooralging aan de vormelijke levering door mancipatie. Het gat in de oorkonde om een frai voorbeeld van een schriftelijk vastgelegde manciparie: na de anhef zijn nadere bepalingen (sub II: de leges mancipio dictae) opgenomen. In III wordt vastgelegd dat de mancipatio tegen symbolische prijsbetaling van 1 sestertie heeft platsgevonden. In IV vind men dan een verklaring omtrent de in bezutstelling en een voorbehoud voor de ter aardebestelling van het stoffelijk overschot van de schenker; in $V$ een opsomming van de getuigen. De leges mancipio dictae zijn gegoten in de vorm van een zelfstandige stipulatio, en vervolgens vastgelegd in de akte die van de mancipatie is opgemaakt: de latste passage onder II, 9 waar het juridisch-technische wormelijke woorden paar stipulari - spondere wordt gebruikt, levert hiertoe onweerlegbaar bewijs en illustreert hoe in de praktijk tot diep in de periode van het klassieke recht de stipulatio en de mancipatio, beide streng vormelijke rechtshandelingen naar ius civile, in samenhang werden gebruikt. ${ }^{84}$ Zoals ook in andere mancipatie oorkonden gebruikelijk, wordt de weegschaalhouder (libripens) bij name genoemd in het "verslag' van de mancipatie zelf (sub III). Het vereiste aantal getuigen wordt met één persoon overschreden (V).

Het interessantst zijn de leges mancipio dictae, de voorwaarden waaronder de schenking plaats vindt en die afgesloten worden met een zelfstandige stipulatio poenae. Hoewel zij duidelijk zijn geformuleerd en aan de intentie van de schenker niet gerwijfeld kan worden, blijven er strikt juridisch wel enige onzekerheden. Evenals bij andere schenkingen of makingen, watabij de schenker c.q. erflater probeerde om over het graf heen te regeren en zijn nam voor

81. Paul. Dig 41,2,3,32; Pomp. Dig. 41,2,26. Voor problemgerallen zic bive Scarv. Ding. $19,1,48 ;$, Dul. Dig. 19,1,42.

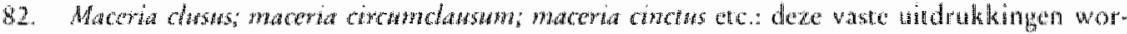
den wet gebruikt: CIL V, 3202; VI, 13823; 22437; 23090; X, 6069; XIV, 3340; 379\%. Z he voor wacte omschrifvingen wan percelen grond bijw. nog de Donatio lutide Monimes (FIRA III, n. 93). 1-6; Domatio Siatiae Irenes (FIRA III, nir 95), r. 17, Emprio domus (FIRA III, n

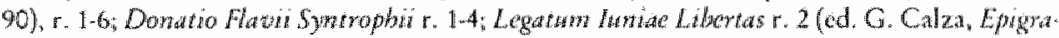
fict 1939 , p. $160 \mathrm{cow})$

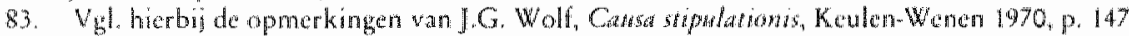
nt 93 .

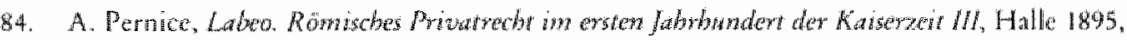
p. $146-150$. 
vergetelheid te behoeden ${ }^{85}$, crecert ook deze weldoener een regiem met een wankel evenwicht, dat het na zijn dood wooral zal moeten hebben van uitwoering te goeder trouw. In de eerste plaats legt hij Aithales - en zijn erfgenaam en "alwie de zaak aangaat of zal aangaan" 86 (sub II aanhef) - op diegenen van zijn mannelijke en wouwelike slaven die hij bij testament of codicill zal heb. ben wrijgelaten, te laten delen in de cigendom van zijn tuinen. Die medeeigendom zal derhalve te zijner tijd nog gevestigd moeten worden, wellicht door stipulatio en mancipatio onder dezelfde voorwarden als geformuleerd in de onderhavige acte, na de dood van Syntrophus. Vervolgens krijgen de begunstigden wen antal bevoegdheden (sub II, 2-6) roebedeeld: gezamenlijk hebben zij het recht de wruchten en opbrengsten te genieten, die zij pondspondsgewijze onder elkaar moeten verdelen. Hoewel er een volgorde wordt genoemd in $\mathrm{I}_{,}, 3$ - de door Syntrophus wrijgelatenem, dan hun kinderen en pas dan hun wrijgelatenen - vindt verdeling naar evenredigheid plaats, ongeacht status en graad. Bewoning van het huis is toegestaan bij unanieme instenming van alle belanghebbenden en, zo deze niet verkregen wordt, bij meerderheidsbesluit. Deze bewoning wordt meeberekend in de opbrengst, wanzelfsprekend onder aftrek van het kostenbestandde $\mathbb{l}$ voor onderhoud en her oogsten van de wruchten. In II,7 komt de neiging wan Syntrophus zijn nagedachtenis niet in vergeteltheid te doen geraken nog eens onverholen en verder reikend dan rechtens mogelijk was, naar voren: de laatstlevende van de makomelingen van zijn vrijgelatenen moet in zijn testament de naam van de oorspronkeijike weldoener bewaren en de goederen onder dezelfde bepalingen vermaken. Hier is het leven sterker geweest dan de leer: een dergelijke opdracht had naar Rom meins recht geen enkele rechtskracht: meer dan een morele gehoudenheid kon in deze beschikking niet gelegen zijn. De jurist die voor Syntrophus de acte heeft opgesteld, zal wel met een schouderophalen aan diens vurige wens gehoor hebben gegeven in het besef dat de praktik aan het geschrevene te zijner tijd ieder gewicht wel zou ontriemen. Deze instructie roept reminisensies op aan de vele vervreemdingsverboden, die erflaters op hun grafmonumenten

85. Dic nype beshikking kwam veelvuldig woor in testamenten, zie bij. Paul. Dig. 31,88,6;

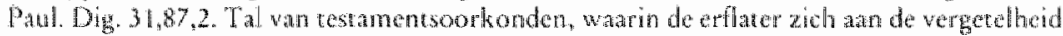

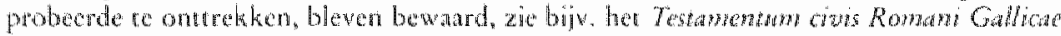

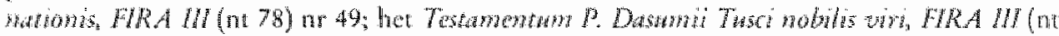

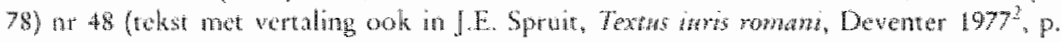
$211-218)$.

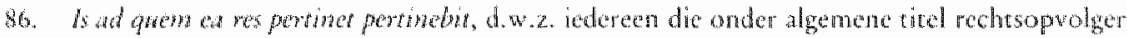
wordt. wg. Panul. Dig. 50,16,70; Mod. Dig, 44,7,53,1. Men vindt deze passage wrij vake, zie bijv. Ulp. Dig. 3,3,33,3; Ulp. Dig, 3,3,39,1-2; Paul. Dig. 45,1,126,2, lul. Dig. 46,8,22,7. 
lieten inscriberen en die zich in vele gevallen ook tor de ruinen waarin hun romben gelegen waren uirstrekten. ${ }^{87}$

Flavius Syntrophus zal zich well hebben gerealiseerd dat er voor schending van zün statuut tal van mogelijkheden waren. Niet woor niets neemt hij dan ook in III, 8 een clawstala dol, versterkt door een schadevergoedingsplicht voor quanti ea res est plus een zelfstandig boetebeding op: ab hac re promissio. neque dolus malus cuiws vestrum, de quibus agitur, absit, ten anzien van deze angelegenheid en deze belofte zal bedrog bij teder van u die deze zak angaat, afwezig zijn. Zowel de ontvanger Aithales als zijn ertgenamen als ook alle begunstigde vrigelatenen met wie eerswgenoemde van de tuinen met toebehoren zal mogen genieten, dienen zich van arglistige interpretaties en onbehoorlijk gedrag te onthouden. Deze clausule werd vooral vak in testamenten opgenomen ten einde uitleg in een richting die contrair was aan de bedoelin. gen van de erflater te voorkomen. ${ }^{83}$ Bij rechtshandelingen onder de levenden verschint de clausule nog al eens in stipulaties. ${ }^{89}$ Voor Aithales betekent de acceptatie van deze clausule niet alleen dat hij en zijn rechtsopvolgers onder algemene titel zich van doleus gedrag moeten onthouden, maar ook een actieve zorgplicht ${ }^{90}$ ervoor te waken dat derden geen inbreuk zouden maken op het samenstel van rechten en verplichtingen dat Syntrophus in het leven had geroepen. Naast een schadevergoeding voor quanti ea res erit is er, om. kortsluiting van alle discussies te voorkomen, in een stipulatie nog eens een bedrag van 50.000 sestertiën als vaste boete opgenomen ${ }^{91}$, dat door de erfgem namen van Flavius Syntrophus bij schending van ieder van de opgenomen voorwarden zou kunnen worden ingevorderd, zonder dat daardoor de actice zou worden geconsumeerd. Dit had het tot gevolg dat, war Aithales zicli bij zin vormelijke toezegging sterk maakt voor zijn toekomstige medevriggelate-

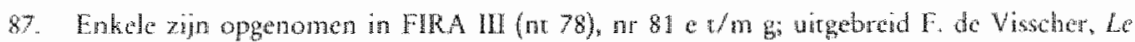

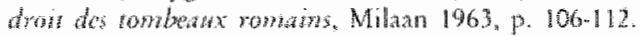

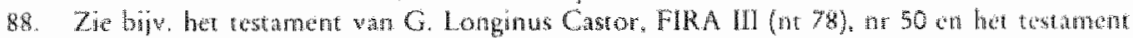

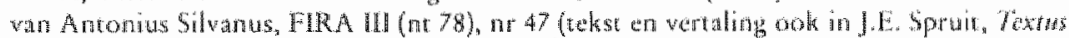

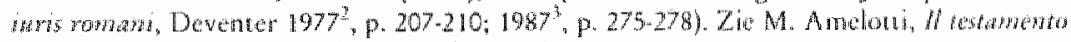

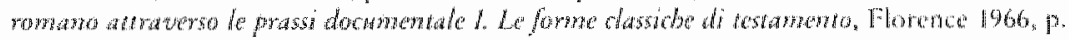
$163-165$.

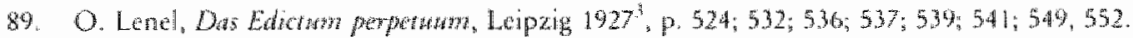

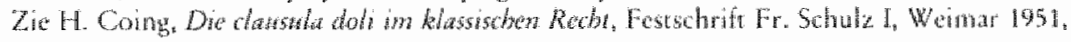
p. $9 \%-124$.

90. Wgl de opmerkingen over deze gewoonte bij Vot., Dig. 46,5,11 alsmede in Inst $3,15,7$. Het bedrag van 50.000 scsterten was gebruikelike Pap. Dig, 45, 1,85,3; Scow. Dig. 45, 1, 122,2 .

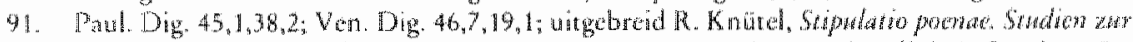

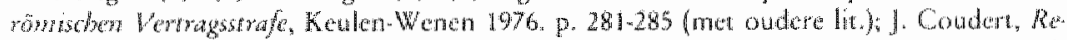

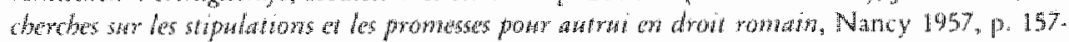
158. 
nen, de stipulatie gericht op de schadevergoeding alleên geen effect had kunnen sorteren ${ }^{92}$ woor deze derden kan hij nier roezeggen dar zij zich van dolws zullen onthouden. Wel zal het altijd verstandig zijn dat Aithales zich na de dood van Syntrophus, alvorens zijn medebegunstigden door mancipatio ton het genot van diens tuinen toe te laten, eerst bij stipulatio exact hetzelfde laat beloven als wat er in de acte russen hem en Flavius Syntrophus staat, een en ander onder opname van een identieke clausula dol, schadevergoedingsplicht en boetebeding.

\section{Erfdienstbaarheden}

In het kader van het leerstuk der erfdienstbaarheden speelt de tuin, in het bijzonder de siertuin (viridarim) eveneens een kleine rol. Het oude, nog steeds geldende principe 'servitus in faciendo consistere nequit' wordr door de klassieke juristen ${ }^{93}$ casuistisch aan de hand van tuinaanleg uirgewerkt: Pomponius stelt dat het rechtskarakter van een erfdienstbaarheid niet gelegen is in een positief handelen, een standpunt dat hij illustreert met her voorbeeld dat iemand als eigenaar wan het dienend erf verplicht zou zijn een siertuin aan te leggen of voor een fraai uitzicht zorg te dragen. ${ }^{94}$ Degene die met een glimlach mocht menen dat het hicr om een antick voorbeeld gaat en dat over zulke basiskwesties geen verschil van mening meer kan bestaan, zij verwezen naar een geding dat enkele jaren geleden voor het Hof te 's-Gravenhage diende, waarin eveneens de vragg of en in hoverre een erfdienstbaarheid van siertuin bestaanbaar was, werd behandeld. ${ }^{95}$ Iavolenus zondert, voor zover het gaat om gebouwen, het uiridarim uit van het servituut wan niet hoger bouwen.96 In de anieke literaire en epigrafische bromen wordt het viridanum enkele malen genoemd zonder dat daarbij op de opzet en het karakter van dit tuintype word ingegaan. ${ }^{97}$ De juristen noemen het om hun stellingen te illustreren: wit hun voorbeelden valt op te maken dat het steeds om tuinen met een beperkte oppervlakte en met een beplanting van bloemen en laagblijvende

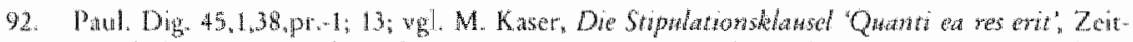
sehrife der Savigny-Sitning fir Rechesgeschichte, rom. Abt. 90(1973), p. 192-199(met lit).

9) Pomp. Dig. $8,1,15,1 ;$ Pall Dig. 33,1,12; C. Aquilins Gallus bij Ulp. Dig. $8,5,6,2$.

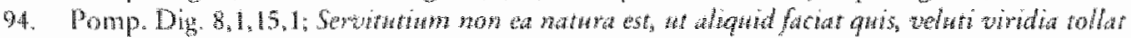

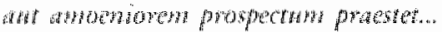

95. Hof 's Grawenhage \$-12-1983, NJ 1985, ar 181 .

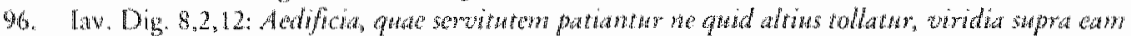

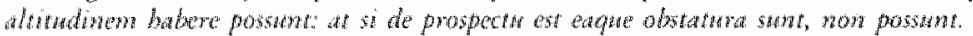

97. Bronmen in Oxfon Latun Dicronary II, Oxford 1976, p, 2072. 


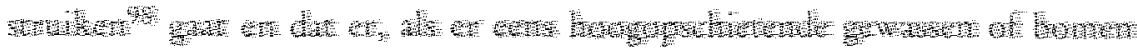

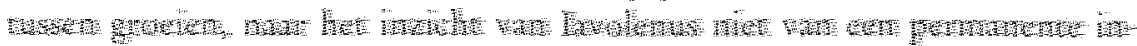

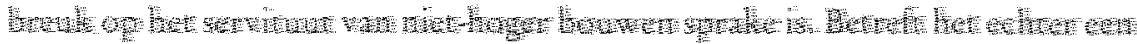

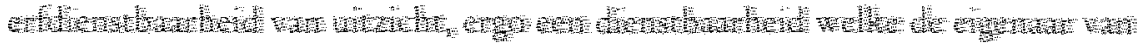

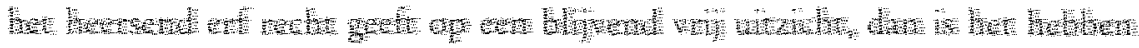

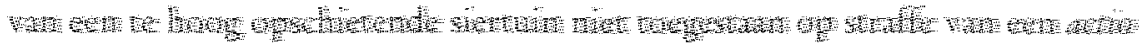

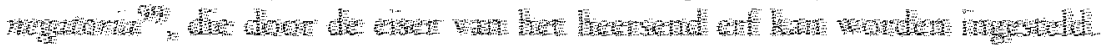

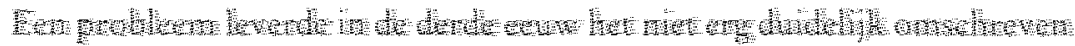

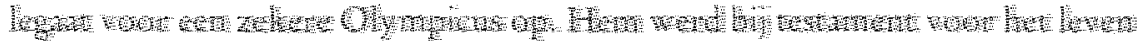

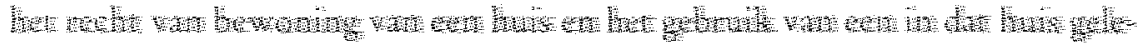

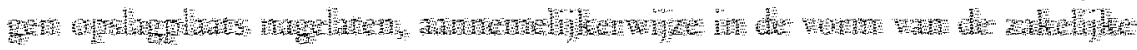

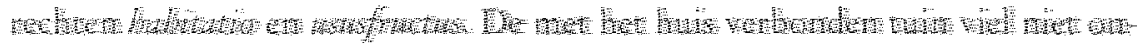

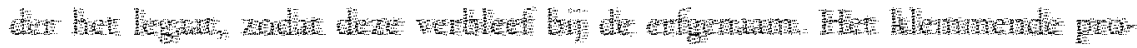

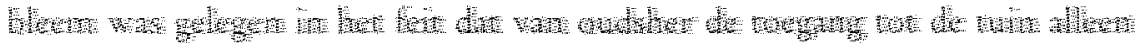

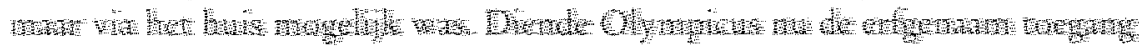

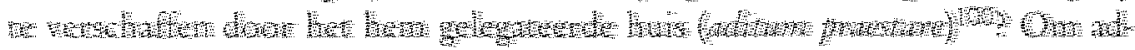

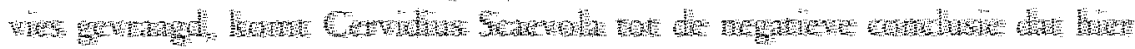

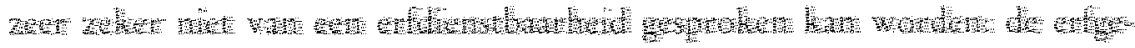

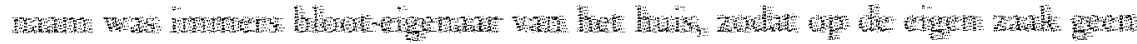

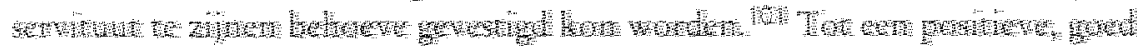

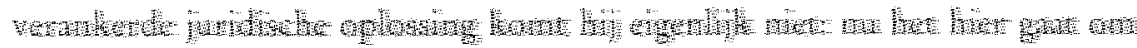

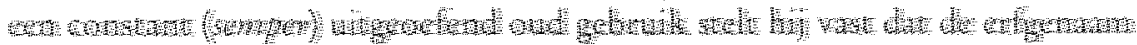

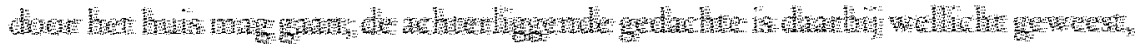

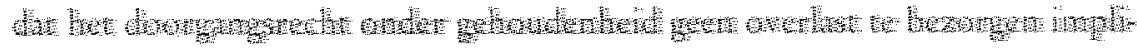

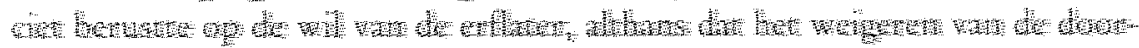

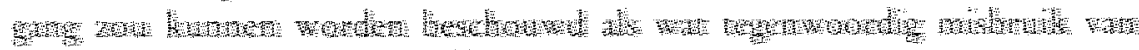

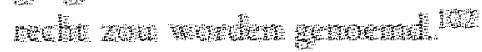

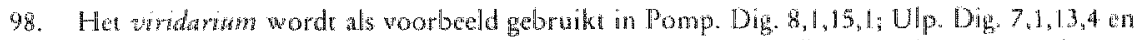

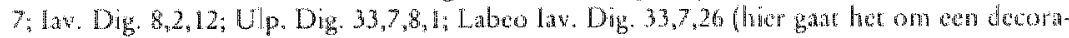

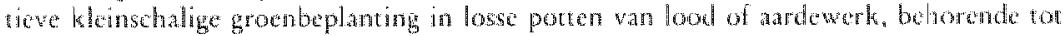

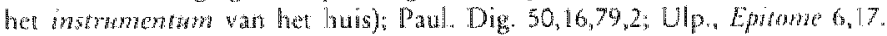

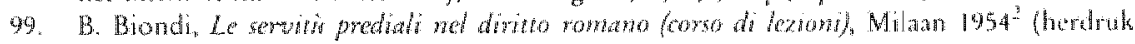
$19691,0.343,34$.

100. Omgekerde gevallen bij Iul. Dig. 30,1,81; Marc. Dig. 33,2,15,1 (toegangsrecht van de wruhtgebruiker resp. bewone tor her terein wan de erfgenam).

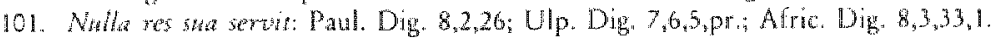

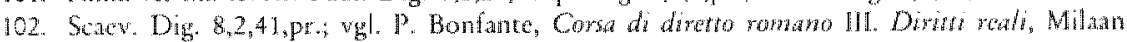
$192^{2}$, p. 147; B. Biondi, La categoria romana delle serokites, Milan 1938, p. 239-241, ovet her begrip "misbrutk wan redre", dat in zijn rnoderne vormgeving niet van de Romeinse juristen atkomstig is: J.E. Spruit, Malims non indulgendum esse, Brocardica in honorem C.C.J. wan den Bergh - 22 studies over oude rechespreuken, Deventer 1987, p. $95-101$. 


\section{$X$ De tuin als object van vruchtgebruik}

Voorts moet het in de maatschappelijke praktijk veelvuldig zijn voorgekomen dat tuinen in vruchtgebruik werden gegeven. Dit ligt ook wel voor de hand: via dit zakelijk genotsrecht was het mogelijk aan bepaalde personen die iemand na aan het hart lagen, voor de duur van hun leven het gebruik en de opbrengsten van een zaak ter beschikking te stellen om tenslotte deze zaak zelve in vol genot bij de bloot-eigenaar te doen komen. De in vruchtgebruik gegeven tuin speelt hier en daar een rol in het juridisch tekstmateriaal, vooral daar war het vragen rondom de zogenaamde mutatio rei betreft. Rei mutatio amittitur ususfructus, door ondergang of verandering van de zalk gaat het vruchtgebruik verloren, aldus Paulus ${ }^{103}$, warbij het er dan om gat dat de verandering geleid heeft tot een nieuwe zaak (nova species). Dat in tal van concrete gevallen vragen over het al dan niet veranderd zijn van een in vruchtgebruik gegeven zaak tot discussies konden leiden, ligt voor de hand.

Het is weer Ulpianus, bij wie in dit verband de ruin nogal eens als voorbeeld wordt gebruikt. De vruchtgebruiker, zo zegt hii, mag de positie van de bloot-eigenaar niet slechter maken, wèl verbeteren. ${ }^{104}$ Als voorbeeld van het eerste noemt Ulpianus het omhakken van de vruchtbomen of het neerhalen van het landhuis, wanneer iemand het vruchtgebruik wan een boomgaard is nagelaten. En nog sprekender is zijn aan de stedelijke cultuur ontleende waarschuwing: als er bijvoorbeeld een uitsluitend voor het welzijn bestemd stuk grond (praedium voluptuarium) is, dat groenvoorzieningen, wandelpaden (gestationes) of brede, lommerrijke en lieflijke lanen (deambulationes) met nietvruchtdragende bomen heef, zal hij dit niet via een kaalslag mogen ombouwen tot een olijventuin of iets anders dat gericht is op het verkrijgen van opbrengsten. ${ }^{105}$ Deze uitsprak moet gebaseerd zinn op een kwestie die zich binnen een welgestelde familie in een urbane omgeving kan hebben voorgedaan. Ambulationes waren wandelpaden waarop men te voet, bij voorkeur in goed gesprek mer een ander, kon gaan en kon genieten van fraai aangelegde groen-

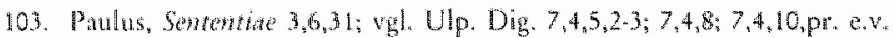

104. Ulp. Dig. $7,1,13,4-7$

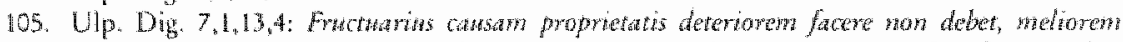

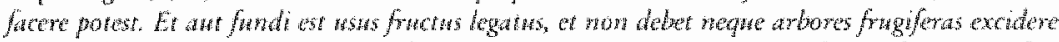

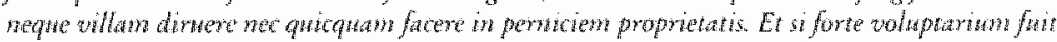

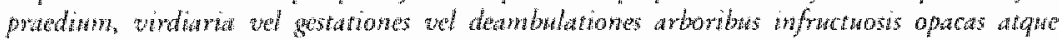

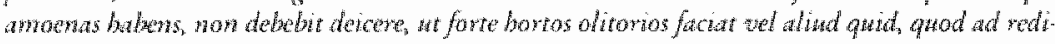
then spectits. 
voorzieningen. Grotere tuinen waren bovendien voorzien van getationes 106 , bredere lanen warover een tocht per draagstoel of - indien men geen bezwaar had tegen enig gehobbel - per koets of kar gemakt kon worden. Er zijn indicaties dat onze antieke voorvaderen deze paden en lanen niet alleen hebben gebruikt voor rustige wandelingen, maar ook om er te trimmen en hun hichaamsconditie op peil te houden. ${ }^{107}$ Iuvenalis 108 meet in cen van zijn saciren iemands nijkdom af naar de lengte van zijn lommerijke paden, die meestal vrij zorgvuldig waren aangelegd om er het wandelen of rijden zo aangenaam mogelijk te maken. ${ }^{109}$ Ulpianus moet her vruchtgebruik van een kapitale tuin in gedachten hebben gehad. Een dergelike tuin een herbestemming tot oljvenhof of moestuin te verlenen en sierbomen te vervangen door vruchtbomen betekende een duidelijke mutatio ret, die cor her tenietgaan van het vruchtgebruik en aanwas bij de bloot-eigendom ${ }^{110}$ zal hebben geleid.

Een ander voorbecld van mutatio rei van het vruchtgebruik wordt door enkele juristen bediscussieerd aan de hand van overstroming van een tuin. Quintus Mucius Scaevola en Labeo pleitten voor behoud van het recht, als de rivier zich weer terugtrekt: bloot-eigendom, vruchtgebruik en eventuele erfdienstbaarheden herleven dan in hun oude gedaante. De duur wan de overstroming speelde geen rol. Iavolenus nuanceert het oordeel van Labeo enigszins: is de grond warop de tuin was aangelegd niet meer terug te winnen doordat de bedding van de rivier zich daarheen heeft verplaatst, dan is deze publiek eigendom geworden, en is het wruchtgebruik van de tuin verloren gegaan. ${ }^{11}$ Over de tijdsduur wordt in de tekst niets gezegd; volgens de normen van het iws civile gaat, als de inundatie langer dan twee jaren duurt, het vruchtgebruik en eventuele servituten door non usus teniet. Trekt het water zich der-

106. P. Grimal (n 5) p. 269 e.

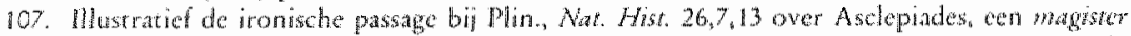

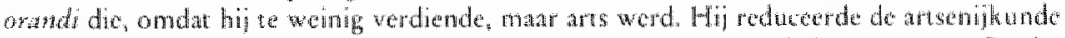

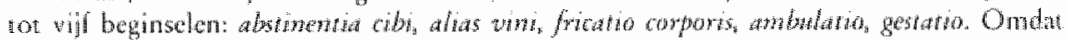
dit bereikbar was vor een ieder en iederen dit ook we besefre, wist de welsprentande $A s e$ -

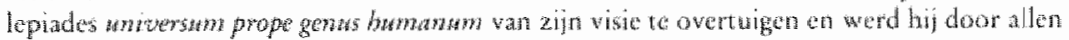
als een toor de hemel gezondene (cato downishs) beschoud.

108. Tuvenalis, Sat, 4,57.

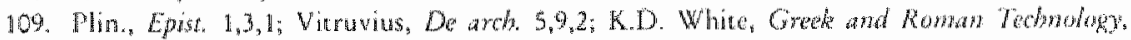
Londen-New York 1984, p. 93.97.

110. Aldus expliciet Up. Dig. $7,1,13,7$ net betrekking tot het legat van het vruchegebuk van cen vinidarrikm.

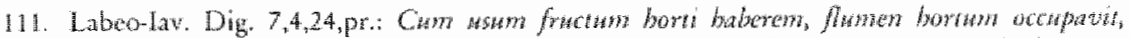

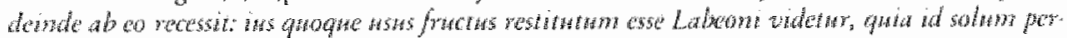

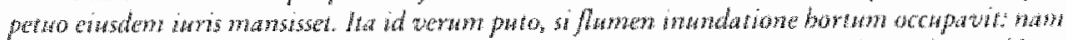

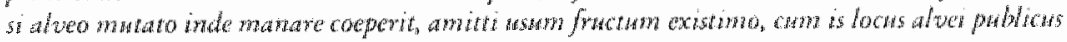
esse coeperit, negue in pristmum statum restinul posse. 
halve later alsnog terug, dan dienen de betrokken rechten opnieuw gevestigd re worden. 112

Bij het zakelijk recht van bewoning dat in zijn functie verwant is aan het vruchtgebruik, speelt de vraag naar de omvang van het gebruiksrecht evencens cen rol. De juristen verschillen daarin op tal van punten aan mening: in ieder geval mag de gerechtigde op het omliggende terrein gaan en staan watr hij wil. De juristen Sabinus en Cassius staan hem het gebruik van de tuin toe ten einde zich voor dagelijks eigen gebruilk van fruit, groente, bloemen en water te voorzien; verkopen om wat bij te verdienen, mag hij deze produkten echter miet. Andere juristen leggen weer andere accenten. Ulpianus makt aan de kibbelarij een einde. Het hangt er maar yanaf - zo zegt hij - warop men zijn recht van bew oning heeft: heeft men een recht van bewoning ten plattelande en brengt het land woldoende op, dan is er niets op tegen om fruit, groente, bloemen en hakhout niet alleen ter plekke te gebruiken, maar ook er in de stad iets van ten verkoop an te bieden. ${ }^{113}$ Ulpianus pleit als goed jurist voor een casuistische oplossing al nar gelang de omstandigheden waronder het recht verleend is.

Ook in andere juridische situaties kunnen ingrijpende veranderingen die door de bezitter in zijn tuin zijn angebracht, een rol spelen. Zo in het geval dat iemand wijnbergen, boomgaarden en tuinen bezir die object zijn van een erfrechtelijk geschil. Is tegen de bezitcer de hereditatis petitio - dus de actie van de eiser die pretendeert erfgenaam te zijn en uit dien hoofde bezit van de nalatenschap claimt - ingesteld en heeft wellicht, als gevolg van de daaruit voortvloeiende malaise, de gedaagde geen onderhoud meer gepleegd, dan kan hem dit cluur komen te staan. Hij is immers gehouden de tuinen in dezelfde staat te houden als warin deze zich onder de overleden erflater bevonden; verliest hij het geding, dan zal de waardevermindering van de tuinen als gevolg van achterstallig onderhoud door de eiser getaxeerd mogen worden en zal het geschatte bedrag betaald moeten worden. ${ }^{114}$

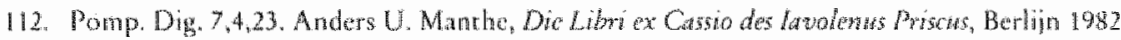
p. $86 \mathrm{nt} 9 \%$, die in de cerste zin het oorded van Q. Muciss lext (iedere overstroming leid

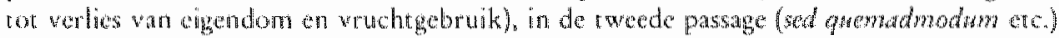

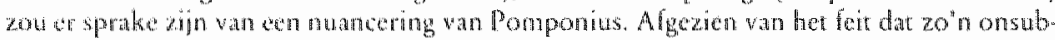

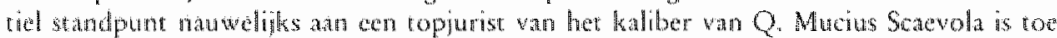

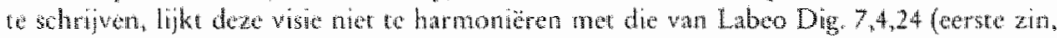
zite noot 98) die slechts enkele decenna later ledte. Zie ook Lav. Dig. 8,6,14,pr.

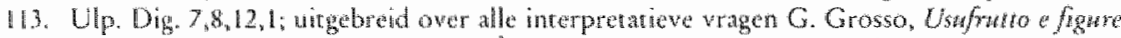

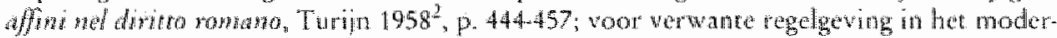
ne reth ate art. $816 \mathrm{BW}$.

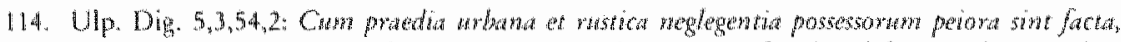

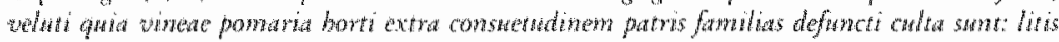

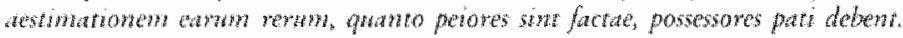


De hierboven beschreven metamorfosen spelen in het kader wan de zakelijke zekerheidsrechten niet zo'n cruciale rol, hetgeen zich lat verklaren uit de doelstelling van deze rechten: ook al is een verhypothekeerde onroerende zaak naderhand wan karakter veranderd - bijwoorbeeld als cen onder hypothecair verband liggend huis is afgebroken en verandlerd in een tuin - dan heefr de zakelijke zekerheidsgerechtigde in ieder geval niet de mogelijkheid verloren om op te treden met de actio bypothecara. 115 Een dergelijke mutatio rei moge dan de processuele positie van de gerechrigde onverlet laten, dat door dit soort ingrijpende wijzigingen in de bestemming iemands zekerheidsrecht inhoudelijk uitgehold kan worden, lat zich toch niet ontkennen.

\section{De twin als object van koop en verkoop}

In Rome bestond een levendige handel in percelen waarop tuinen waren angelegd. Vooral op de rechteroever van de Tiber (trans Tiberm) lagen veel goed te irrigeren weelderige parktuinen, gezochte objecten voor vermogende lieden. Cicero bijwoorbeeld probeert in 45 w. Chr., na de dood van zijn dochter, via zijn vriend Atticus die hij daartoe volmacht geeft, enkele ruine nt te kopen om te harer nagedachtenis daarop een heiligdom re srichten. Zijn gedachten gaan ook uit naar de borti Cottae, gelegen aan de Via Ostiensis. Ook denkt hij aan een ruinencomplex, toebehorend aan M. Livius Drusus (borti Drusi) en andere tuinen elders, die hij te koop veronderstelt. Over de mogelijkheden correspondeert hij op verschillende data met zijn vriend Atticus. 116

Evenals bij percelen met een andere bestemming dan tuinaanleg konden zich ook bij tuingronden conflicten over de omvang ervan voordoen. Kocht men een tuin dan diende het gekochte perceel dus naukeurig omschreven en geidentificeerd te worden. Hierboven ontmoetren wij al een voorbeeld wan cen dergelijke topische descriptie. 17 Door het ontbreken van cen kadaster waren goede situatiebeschrijvingen in de akte alsmede en degelijke en onbetwiste omheining van het beschreven perced van belang. Daarom wordt in de bewaard gebleven akten en in inscripties naast een exacte aanduiding wan

115. Marc. Dig. 20,1,16,2.

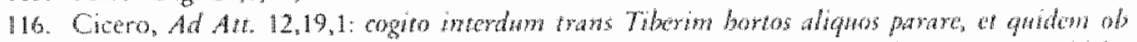

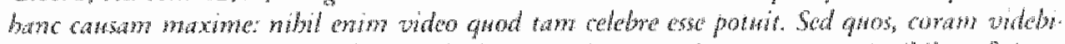

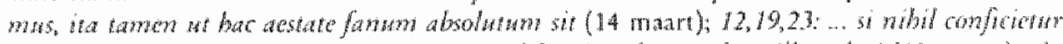

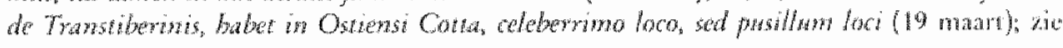
voorts $12,21,2$

117. Zic de arabel wan de schenkingsake van Flaviu Syntrophus op ble. 22. 
de ligging, op de wijze die overeenkom met die in de aanhef van de schenkingsakte van Flavius Syntrophus, ook het feit dat het om een ombeind perceel gaat regelmatig genoemd. 118 .

Bij verkoop van percelen grond, waronder tuinen, was het verstandig om duidelijk vast te leggen wat beide partijen bedoelden. De handel in tuinen had tegen het einde wan de Republiek duidelijk al een vrij grote omvang bereikt. ${ }^{119}$ De grenzen dienden wast te staan, wilde de inbezitneming op grond van koop mogelijk zijn. ${ }^{20}$ Aangeztem in tal van grotere tuinen van vermogende Romeinen grafmonumenten lagen, die onder eer eigen regiem vielen, deden zich op dit punt nog wel eens moeilikheden voor. Meestal lagen deze tomben op een door een omheining afgeschermde plek en vormden zij een gewijde plats Rocus religiosus), indien cen overledene darin ook werkelijk zijn laatste rustplats had gevonden. ${ }^{121}$ Bij verkoop gevolgd door levering behielden dergelijke terreinen hun gewijde karakter met alle religieuze en juridische consequenties, warbij er overigens een tendens is re bespeuren dat erflaters door eigen beschikking het gewijde karakter wan hun laatste rustplaats (sepuhchrwm) ruimtelijk probeerden te vergroten. In inscripties als bic locws cum bortulo religioso, deze plek met zijn gewijde tuin, of buic monumento cedit bortus cum aedificio maceria clusus ${ }^{122}$, de tuin met opstal zoals zij is omheind hoort bij het monumenr, komt men dit streven in allerlei variaties veelvuldig tegen. De juristen, zowel de bij name bekende intrisconsuli als de anonieme op de kanselarij werkzame beambten, werzetten zich tegen deze tendens. Papinianus stelt het dan ook buiten discussie dat loca pura - ongewijde plekken die binnen de omheining aangelegd zijn als tuin of bestemd zijn voor het kweken van gewassen, zaken in de handel ziin en krachtens koopcontract de koper roebehoren. ${ }^{123}$ Wil men de beschikking houden over het graf en de graftombe, dan dient de verkoper daartoe expliciet een voorbehoud in de overeenkomst op te nemen. ${ }^{124}$ Een zelfde neiging tot een restrictieve interpretatie

118. Zie ne 82

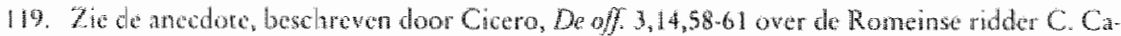

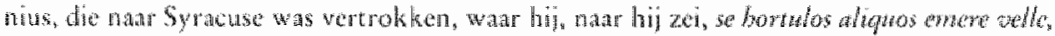

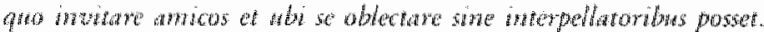

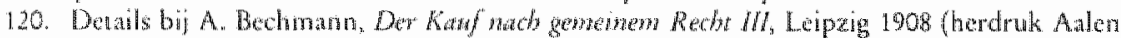
1965). p. 23.29.

121. Mace Dig. 11,7,37, Marc. Dig. 11,7,3\%, Celsus bij Ulp. Dig. 11,7,2,5.

122. CLL VI, 22518; 23090; ze in gelijke geest bijv. CLL V1, 1396; $13823, X 2015 ; 3750=$ FIRA

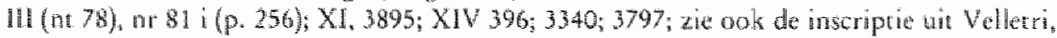
FRA $111($ (nd 78$)$, ne $81 ;($ p. 256)

123. Pap. Dig. 18, 1,73,1; in grelike zin Ulp. Dig. 18,1,22,24.

124. Pap. Dig. 18, 1,72,1; Labeo Dig $19,1,5,1$. 
van het begrip locus religiosus windr men - om fiscale redenen - in keizerlijke verordeningen terug. 125

Dat tuinpercelen voorts het object waren van privaatrechtelijke rechtsverhoudingen waarin de mogelijkheid van noodgedwongen verkoop op de achtergrond een rol speelde, ligt voor de hand. Noodgedwongen, bij: als gevolg van intimidatie (metws), vitgeoefend door de wederpartij, bijv. een hooggeplaatste stedelijke overheidsfunctionaris. Wanneer men huis en tuin verkoopt onder druk, in de hoop daardoor te ontkomen an belastende publieke munera of daardoor exn acte met een belastende schuldbekentenis terug te krijgen, is dit niet voldoende grond voor het inroepen van nietigheid van de koopovereenkomst, aldus Diocletianus in een reseript, gericht tot de verkoper Trophimus ${ }^{126}$; de leverng (traditio) behoudt in de lat-klassieke watgeving derhalve geldigheid, vermoedelijk op grond van het door Paulus verdedigde coactus volui-principe. ${ }^{27}$ Men kon zich ook zell in een situatie brengen dat 'noodgedwongen' verkoop moest plaatsvinden. Uit een door Cervidius Scaevola behandelde interpretatiekwestie omtrent de omvang van een door de legataris van de erfgenaam te vorderen bedrag biijkr dat ruinpercelen zelfstandig als pandobject konden fungeren ${ }^{128}$, hetgeen bij niet-betaling van de schuld kon leiden tot realisering wan zijn positie als separatist door de crediteur. Ook een rescript van Septimius Severus illustreert dit nader. De keizer stelt vast dat ingeval tuinen in pand zijn gegeven door een bij her aangaan van de overeenkomst daartoe niet gerechtigde, de crediteur zijn pandrecht niet kan uitoefenen, tenzij hij erin slaagt te bewijzen dat de gedaagde wel bewust heeft meegewerkt an het bedriegen van de crediteur door net te doen allsof de tuinen hem toebehoorden. ${ }^{129}$

Heel veel later, in 535, worden met het oog op mogelijke verkoop de tui-

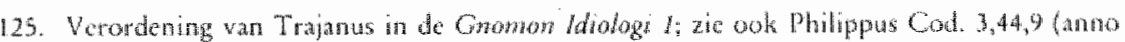

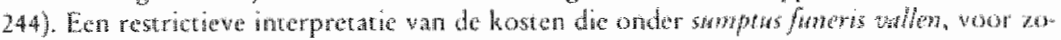
wer deze betrekking haben op een grafmonument, ook bil Macer Dig 11,7,37,

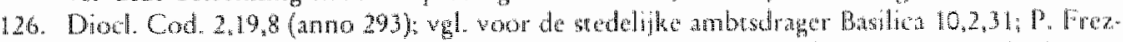

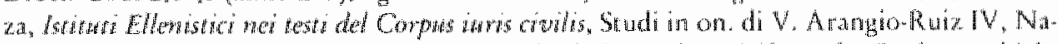
pels 1953, p. 218-221; hierbij H. Kreller, Zeitschrift der Savigny-Stifung Gir Rechesgeshich. le, rom. Abi. 72 (1955), p. 421.

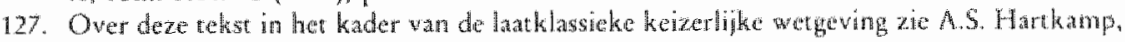

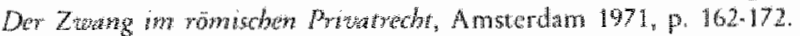

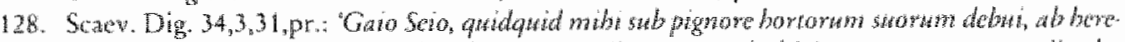
dilw mes dan wolo", aldus luidde de uaterste wil van en schulderen ten gunste wan zijn do. biveur. Zie over de nogeling oorspronkelijke redactie wan dexe passage G. Beselen, Beitrigk

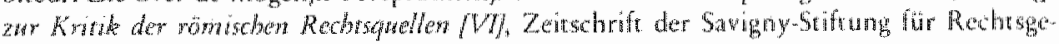
schiches, rom. Abt. 66 (1948), p. 332-333.

129. Cod. 8,15,2; vgl. F. B.]. Wubbe, Res alienzt pignoxt data, Leiden 1960, p. 7: 113. 
nen nog eens genoemd in een Novelle van Justinianus. In het voetspoor van keizer Leo vervaardigt hij een verbod uir op het vervreemden van keizerlike goederen; onder de onroerende goederen die onder dir verbod vallen, worden bij herhaling tuinpercelen met zoveel woorden genoemd in de omstandig geformuleerde constiutio, die verkopen, schenken, ruilen, onder hypotheekstelling belenen, in erfpacht uitgeven, kortom alle rechtshandelingen die tor vervreemding van het desbetreffend perceel kunnen leiden, onder het verbod brenge. ${ }^{130}$

\section{Restitutie van kosten}

In een aantal gevallen hebben laatklassieke juristen als Ulpianus en Paulus zich de vragg gesteld of en in welke mate kosten besteed aan een tuin door anderen dan de uiteindelijk rechthebbende,gerestitueerd dienen te worden. De eerste is Ulpianus, waar hij schrift over de impensae voluptuosae, de kosten dienende ter verfraaing van een object, in casu voorwerpen behorende tot de bruidsgave (dos) die van de zijde van de vrouw aan haar toekomstige echtgenoot werd verstrekt. Als deze staande huwelijk onkosten had gemaakt om een tot de dos behorende zaak te werfraaien, kon hij na beëindiging van het huwelijk deze kosten niet in mindering brengen op het totaal van zijn verplichtin" gen. Dit lag anders met de impensate necessariae, de noodzakelijk gemaakte kosten tot onderhoud, en de impensate utiles, de kosten gemaakt ter verbetering van de zaak: deze konden door de man, wanneer hij de bruidsgave moest resticueren, daarvan afgetrokken worden. ${ }^{131}$ Ulpianus wijst als voorbeeld van impensae voluptuosae op die, gemaakt ten behoeve van de aanleg van een viridarium ${ }^{132}$, een met bloemen en lage beplanting aangelegde siertuin die door de man tot ontwikkeling is gebracht op een tot de bruidsgave behorend percel grond. De gewezen echtgenoot kan daarop geen retentierecht uitoefenen ten cinde de door hem gedane uitgaven terug te Krijgen. ${ }^{33}$ Zijn tijdge-

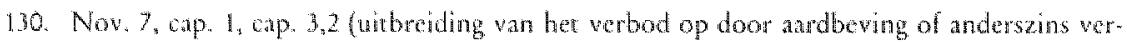
woese gebouwen en (winen); cap. 6,pr. (werval van her geteende bedrag aan de kerk, indien her verbod wordt geschonden on toch zekcheid is verteend op een kerkelikg gebouw ter. rein of (uin).

131. Ulp. Dig. 25,1,5,pr, Ulp., Epitome 6,1417; Paul. Dig. 50,16,79; Kaser I (nt 31), p. 339.340.

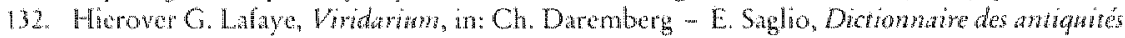

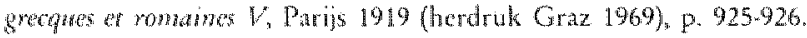

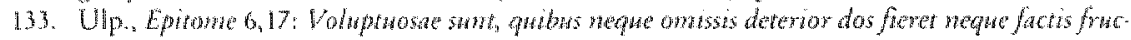

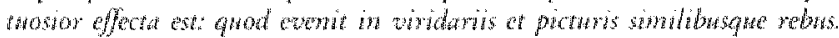


noot Paulus is dezelfide mening toegedaan, zoals blikt uit een passage uit diens Commentaar op Plautius. Ook hij noemt als voorbeld van impersute voluptu. osae, die weliswar bevorderend werken op de schoonheid van het object, maar aan de opbrengst ervan niets wezenlijks toevoegen, siertuinen, fonteinen, fresco's, pleisterwerk. ${ }^{134}$ Het is duidelijk dat door de gemiddelde Romeinse burger siertuinen als een overbodige luxe werden beschouwd, niet onbegrijpelijk in een samenleving die in de eerste plats op economisch nut, opbrengsten en simpel overleven was gericht. De juristen conformeren zich in hun feitelijke illustratie van wat zij als kosten ter verfraaing beschouwen aan deze zienswijze, die overigens niet zoveel verschilt van de onze.

In een vraagstelling omtrent de mogelijkheid van retentio ma ontbinding van het huwelijk speelde de tuin ook een rol, zij het een juridisch nauwelijks relevante. De casus is, opgetuigd met vrij veel feitelijke gegevens, voorgelegd aan Cervidius Scaevola. Enkele dagen voor haar huwelijk wordt een jong meisje ondergebracht in een klein paviljoen, dat enigszins geïsoleerd in de tuin van haar toekomstige echtgenoot gelegen is. ${ }^{135} \mathrm{Op}$ de dag van haar huwelik ontvangt zij vlak voor de voltrekking ervan een schenking van 10.000 sestertiën, een bedrag dat zij overeenkomstig de bestaande praktijk ${ }^{136}$ als bestanddeel van de bruidsgave (dos) aan haar man restitueert. Het huwelijk strandt, de rozegeur en maneschijn in de tuin behoren tot een ver verleden, naar blijkt uit de door materialistische overwegingen ingegeven vraag van de gewezen echtgenoot aan de Scaevola. Hem legt hij de vraag voor of hij de als donatio ante nuptzas geschonken 10.000 sestertiër mag afhouden van de te restitueren dos: omdat het hier geen verboden schenking tussen echtgenoten, maar tussen verloofden betrof, luidt het antwoord terecht in negatieve zin.

In een geheel ander verband kwam de omvang van de kostenvergoeding van een gevolmachtigde aan de orde. T. Aurelius Quietus, een vooraanstaand Romein, consul in 82 , een vriend van Plutarchus ${ }^{137}$ vraagt aan een bevriende arts die in het gelukkige bezit van tuinen in Ravenna was, of hij or, zoals hij

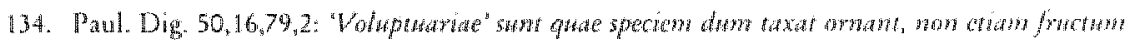

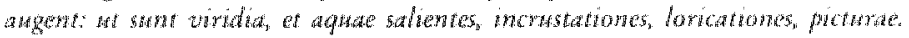

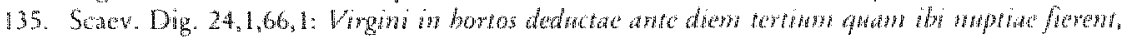

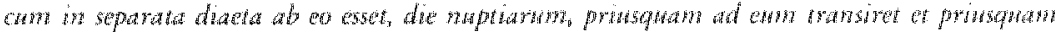

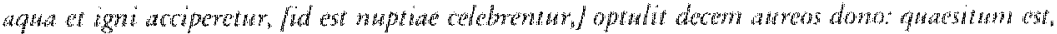

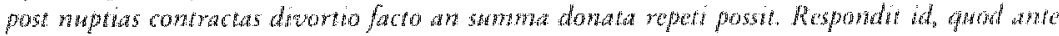

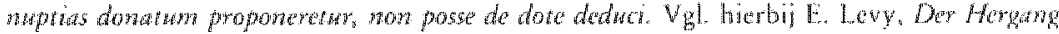
der romischen Eheschedurg, Weimar 1925, p. 7172 ; Kaser 1 (ne 31), p. 74 nt 17 (met lit.).

136. Kasier II (n 31), p. 197 198.

137. Detals bij E. Groag - A. Stcin, Prosopographa Imperia Romani I, Berline-Leprigg 1933. p. $324-325$ (nr' 1592$)$. 
dat gewoonlikh placht te doen, mag gaan kuren. Ten einde zijn weerstandvermogen nog wat verder op te vijzelen, geeft Aurelius Quirus de arts opdrach om er een kaasbaan (spbaeristerium), een via onderaards gelegen ovens gevoede sauna (bypocausta) en enkele andere gezondheidbevorderende voorzieningen an te leggen. Het geschil ontstaat, wamneer de arts de gemaakte kosten met de actio mandat contravia terugvordert. Nu het mandaat een belangrijk clement van een mandatwo tha gratia bevat, neemt Ulpianus - die de kwestie in het voetspoor van Celsus meer dan een eeuw larer nog als cen cause celebre behandelt - een subtiel russenstandpunt in: de arts, wiens tuinen door deze werken in warde zijn vermeerderd en die de bouw ervan ook te eigen behoeve heef uitgevoerd, kan slechts terugkrigen quod amplius impendisset, dus wat hij meer heef mocten uitgeven dan de objectief vast te stellen waardestijging van zijn percelen bedraagt. ${ }^{138}$

\section{Wettelijke bepalingen tegen illegale irrigatie}

Tenslotte is er ook nog een publiekrechtelijk aspect aan het tuinbezit, dat nauw verbonden is met de darop gelegen groenvoorzieningen: essentieel was een goede watertoevoer, In beginsel waren regen-en rivierwater, de zee en de stranden res communes omniam. leder had vrije toegang daartoe en het vrije gebruik van het water. Eigenaren die hun lustoorden aan de oevers van een rivier of van een meer hadden, konden vrijelijk beschikken over het water dat zij, indien en voorzover zij derden daamede geen nadeel toebrachten, desgewenst via een irrigatiesysteem over hun land konden leiden. ${ }^{139}$ In en bij de steden was de situatie gecompliceerder, omdat de watertoevoer hier afhankelijk was van een aquaductenstelsel, dat in het algemeen was angelegd door de hogere stedelijke overheid, soms ook wel door particulieren en voor de ver-

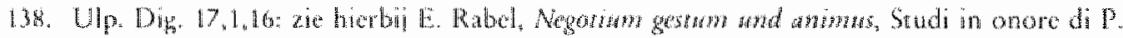

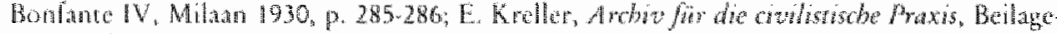

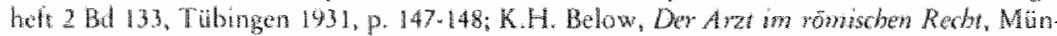
chen 1953, p. 79-80, anders A. Warson, Combact of Mamdate in Roman Lata. Oxford 1961. 1. 120 .

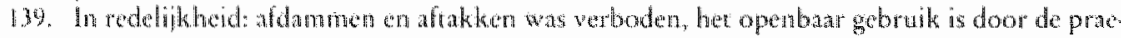

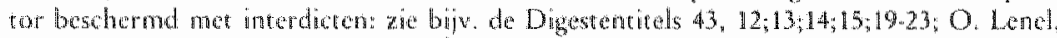

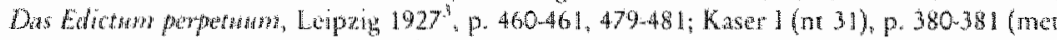

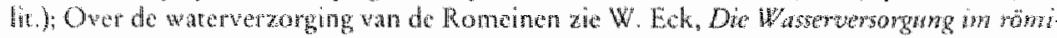

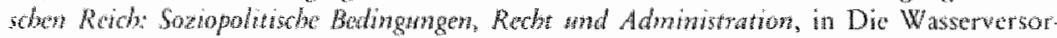

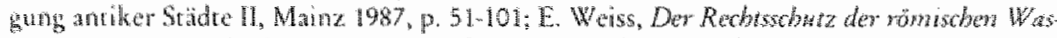

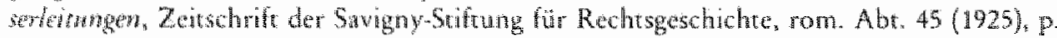
87.10 . 
zorging warwan meestal magistraten met speciale bevoegdheden - in Rome o.a. de curatores aquarm - comperent waren. Een ieder had toegang tor de warervoorrad, die in de antieke steden overigens overvoedig heaft gestroomd. Particuhere anshitungen op de central geleide waterstomen waren zeld. zaam, maar stegen toch beduidend in antal sedert de keizertijd. Ahankelijk wan de ligging van het pand en de financiele stat van zijn bewoner, was in Rome en Pompeji wel een antal huizen op het stedelik waterleidingnet angesloten. "Toch blijft het basisprincipe. geen particuliere anasuiting. Reeds Frontinus schrift dat alleen onder bijzondere omstandigheden an exu ver. dienstelijk burger en dergelijk privilege gegund werd. 140 Omstreeks 440 stat het beginsel dat particuliere ansluitingen alleen bijovervloed aan individuele personen gegund mogen worden, nog steeds vast. ${ }^{41}$ Ook het feit dat de juristen de particuliere waterdragers (aquarit) noemen als behorend tot het vaste bestand der tuinslaven ${ }^{142}$, en dat in inscripties uit later tijd hier en daar een stedelik colleginm aquatormm ${ }^{143}$ wordt vermeld, wijst erop dat het putten en dragen van water de meest verbreide wijze van verkrijging ervan is geweest.

Een heel ander soort indicatie voor de relatieve zeldzanheid van ansluitingen op het locale waterleidingnet is de o.m. tot tuinbezitters gerichte verboden om water af te tappen. De eerste mal dat een dergelijke bepaling wordt opgenomen in een wettelijke regeling is in het kader van de wit medio $9 v$. Chr. daterende Lex Quirctia de aquaeductibus ${ }^{\text {H4 }}$, een wet atkomstig van $\mathrm{I}$. Quinctius Crispinus Sulpicianus en overgeleverd bij Frontinus - die varat 97 directeur van de stedelijke watervoorziening un Rome was - in diens werk over de waterverzorging in Rome. De tuinbezitcers worden in het eerste artikel reeds genoemd:

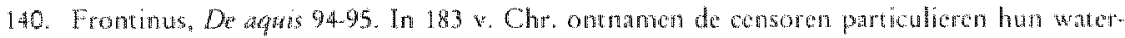

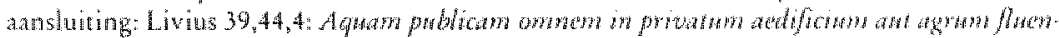
wan adencrint (sc. ansores).

141. Theod. en Valent. Cod. $11,43,5$ in fine.

142. Ulp. Dig. $33,7,12,42$; Paulus, Sententide $3,6,58$; de watedragers in het keizerlik palels worden op inscripties vermald: CIL VI, 131; $551 ; 3953$ e.v; 7973; 8491; 8653; 9131;9445. Keizer Zeno lier de publieke aquari van Constanninopel zelfs brandmerken om te workomen dat zil van hun werk bij de aquaducten door particulieren wegehald zouden worden: Zeno

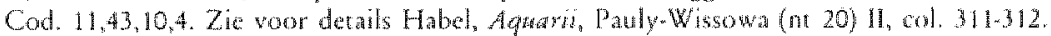

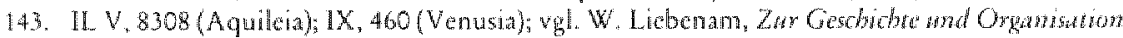
des ronuscher Wereinswesens, Leipzig 1890 (herdnuk Aalen 1964), p. 21.

144. Frontinus, De agnis 129; de her gecrecte wetstekst is ook afgedrukt in $\mathrm{S}$. Ricubono, Fon-

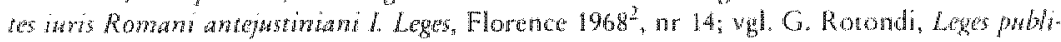
ae populs Ronyani, Milann 1912 (herdruk Hildeshom 1966), p. 453. 
Quetumque post bane legen rogatam riwos specus formices fistulas tobulos castellat lacus aquarum publicarum, quae ad whbem duchntur sciens dolo malo formerit rope-

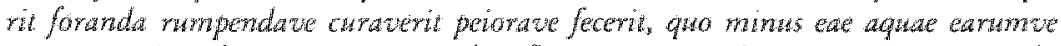
quae gueat in urbem Romam ire cadere fuere pervernire duci quove minus in whe Roma et qua dedificia urbi continentia surat erant, in is hortis praedis locis, quorm bortorum praedionm locorum dominis possessoribus U.F. ${ }^{145}$ acua data ret adtri.

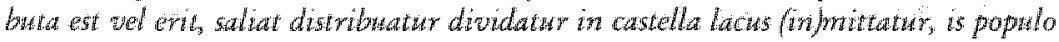

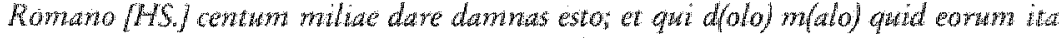
fecerit, id omne sutrcire reficere restituere aedificare ponere excidere demolire damnas esto sine dolo malo...

Hij die na indiening wan deze wet een kanaal, sluis, boog, buis, leiding, reservoir of bassin voor de toevoer van openbaar water naar de Stad opzettelijk met kwaad oogmerk doorboort, vernielt, doet doorboren of vernielen of beschadigt, watrdoor dit water of een gedeelte ervan niet naar de stad Rome kan komen, storten, vlocien, doorstromen of angevoerd worden, of waardoor in de stad Rome of de bebouwing die ann haar grenst of zal grenzen, geen water ontspringt, toegedeeld wordt, toegescheiden wordn, of in reservoirs of bassins verzameld wordt in de tuinen, landerijen, terreinen aldaar, an wier eigenaren, bezitters of vruchtgebruikers water gegeven of toegekend is of zal worden: hij is gehouden aan her Romeinse volk 100.000 sestertién te betalen. Hij die met kwaad oogmerk aldus gehandeld heeft, is bovendien gehouden tor volledige vergoeding, herstel, ongedaan making, herbouw, terugplaatsing, verwijdering of abbrak, zich daarbij onthoudend wan enig kwad oogmerk.

Deze omslachtig geformuleerde bepaling is een van de eerste in een over de tijd gemeten lange reeks verboden om illegaal water af te tappen voor het bevloeien van de eigen tuinen en erven. Hooggeplatste en vermogende personen konden het recht op een particuliere aansluiting wel krijgen, indien zij dienaangaande een rekest aan de keizer zonden. Berichtte deze in positieve zin, dan kreeg de watergerechtigde een keizerlijke epistula, die hij kon overleggen aan de curatores aquarum die dan woor feitelijke uitvoering zorg droegen. ${ }^{146}$ Aan een dergelijke concessic waren in het algemeen hoge kosten verbonden, zodat vooral personen van senatoriale rang, verder ook wel equites en keizerlijke vrijgelatenen bij de begunstigden de overhand hadden ${ }^{147}$, voorzover zij althans mer de keizer goede betrekkingen onderhielden. Het verkrijgen van een recht op water had het karakter van koop of pacht: soms betaalde men cen bedrag ineens, soms ook werden periodicke retributies geheven. In

145. U(t) Kructuriss?

146. Frontinus, De aquas 97-105; details bij E. Komemarn, Pauly.Wissowa (nt 20) IV, col. 1784 1790.

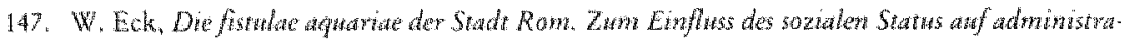

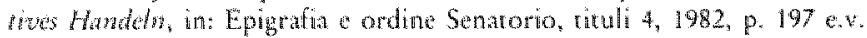


Venafrum bijv. kon krachtens een Edict van Augustus een jarlijke weckgal geheven worden, indien de gemeenteraad hiertoe bij meerderheid van stenmen had besloten. ${ }^{148}$

Minder bemiddelden en personen die geen contact met het keizerlijk hof onderhielden, probeerden hun tuinen van water te voorzien via illegale aftapmethoden of via omkoperij van de agwarij. 149 Voor het behoud van een fraaie tuin was een goede watertowoer, vooral in de zuidelijk gelegen streken, wan essentieel belang. Dat velen zich niet aan de geldende wettelijke regelingen hielden en of meer aftapten dan toegestaan was of aftapten zonder enig recht te hebben en zonder enige betaling, wordt duidelijk uit de herhaalde malen dat in de keizerijke wetgewing tegen deze praktijken wordt opgetreden. Zo bijv. de keizers Arcadius en Honorius, die in 397 aan Asterius, de comes Orièntis, ordonneren on de gebruikelijke warervoorziening als voorheen an particuliere burgers te garanderen en de bestaande privileges voor individuele burgers te continueren. Een en ander onder handhaving van de straf, die diegenen wacht, die tot het bevloeien van hun velden en ten behoeve van een weelderigere begroeing van hun tuinen geheime kanalen benutten. Niet voor miets werd deze constitutie - die overigens het algemeen gebruik primair stelt - zowel in de Codex Theodosianus opgenomen alsook gehandhaafd in de Codex lustinianus ${ }^{150}$ : de praktijk bleek harder dan de leer! De boete in de hierboven genoemde Lex Quinctia was 100.000 sestertiën, een fors bedrag wanneer men bedenkt dat twee jaar eerder dit bedrag bij senaatsbesluit nog op 10.000 sestertiën was gesteld, waarbij volgens de gangbare romeinse praktijk de helf voor de aanklager was. ${ }^{151}$ Confiscatie van de onrechtmatig bevloeide tuin behoorde in de latere keizertijd tot de mogelijkheden. ${ }^{152}$ Ook regen corrupte ambtenaren die immers alle ontduikingen en malversaties oogluikend toelieten, soms na ongekocht te zijn, werden forse geldboetes vastgelegd; dat de overheid in enigerlei periode van de romeinse geschiedenis in staat is ge-

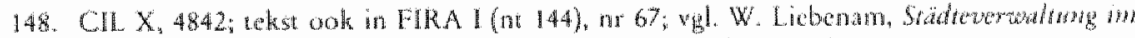

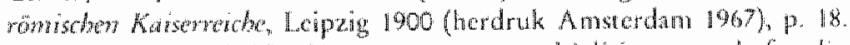

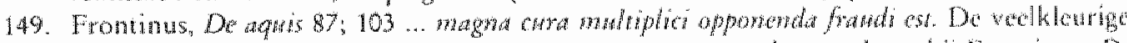
fratdulaze prakrijken on (meer) waver te ontwangen worden geschetst bij Proncinus, Do aquas 112116 .

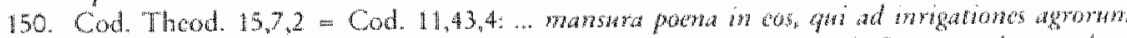

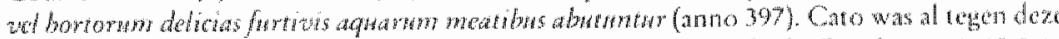
praktiken opgetreden Livis $39,44,4$. Zic ook de verboden in Cod. Theod $15,2,2 ; 15,2,4$.

151. Fromrinus, De ighis 127

152. Frontinus, De agas 97; Cod. Theod, 15,2,4 (ano 389) Zeno Cod. 11,43, Vour Rame: Cod. Theod. 15,2,5 (anno 389 ), voor soortgelike en strengere strafbedreiging legen wat terstatsdelicien zie W. Eck (nu 139), p. 8892 . 
weest de vele misbruiken te beteugelen, lijkt gezien de consistentie warmede de strabepalingen verschijnen, onwarschinlijk. ${ }^{153}$

\section{Slot}

Uit de gevallen die de juristen bespreken en die naturligk enigszins in de marge van rechtsgeleerde kernkwesties liggen, blikt dat de tuin, symbool van rijkdom, vrije tijd en urbane levensculturm, een belangrijke rol heeft gespeeld in het leven vall die Romeiner, die hun bestaan niet behoefden te slijten in een van de vele dicht aaneenliggende woonblokken die Rome rijk was. De tuin makkte, hetzij aesthetisch, hetzij economisch éen geheel uit met het huis en was een asiel warin men wan de dagelijkse zorgen kon wegdromen. Dat ook door de onbemiddelde Romein parken en tuinen werden gekoesterd, kan men zich voorstellen wanneer men zich de toenmalige smalle straten van de stad, de klimatologische omstandigheden, de ongemakken van het dagelijks leven, het gebrek aan goede sanitaire voorzieningen voor de geest haalt, nog daargelaten de armoede warin het overgrote deel van de stedelijke bevolking zijn dagelijks bestaan in overvolle, soms wankel gebouwde woonblokken sleet. In de beward gebleven casuistiek in de literaire, epigrafische en juridische bronnen weerspiegelt zich het belang dat men aan het hebben en behouden van een eigen groenvoorziening of wel aan het exploiteren van een vruchten opbrengende olijven- of moestuin hechtte. Dat men dit belang niet sociaal en juridisch vertaalde nar degenen die zich concreet bezig hielden met tuinarchitectuur en wat tegenwoordig het hoveniersbedrijf wordt genoemd, past in de Romeinse negatieve concepties van arbeid en ambachtelijke werkzaamheden. De tuin 'deed mee' in de dagelijkse beslommeringen var maatschappelijke en juridische aard. De bortus verschijnt weliswaar sporadisch in de bronmen van rechtsgeleerde ard, maar dan toch altijd in het kader van centrale de samenleving regulerende rechtsfiguren: koop, pacht, schenking, vruchtgebruik, erfdienstbaartheden, hypotheek en uiteenlopende erfrechtelijke situaties. Juridische interpretatievragen rondom de bortus bevestigen in dit opzicht uit betrekkelijk onverwachte hoek de vele beward gebleven fresco's in Pompeji, Herculanum en elders. De zorg warmede de panorama's, de parken en terrassen zijn geschilderd, de smakwolle en hoogontwikkelde techniek waarmede de realistische decoraties van planten, bloemen, vruchten en vogels op muren van somptueuze villa's werd aangebracht, illustreren hoe de Romeinen prijs 
stelden op de gerepte natuur, op bedwinging en beschaving van nog woeste, onontgonnen gronden.

In de grote romanistische rechtstraditie sedert de late Middeleeuwen heeft het beward gebleven antieke gedachtengoed rondom de bortus naturilijk geen rol van betekenis gespeeld; daar was ook naw wijks een reden voor. Mar toch: naast de nog steeds voortdurende, intellectueel stimulerende doch op tal van niet met cen eenduidig antwoord op te lossen vragpunten soms bijna tot steriliteit doorgediscussieerde romeinsrechtelijke leerstukken, zou de moderne romanistiek zich het bestaan van vele miniatuurthema's in de geest van het thans gekozen onderwerp in sterkere mate kunnen aantrekken. Gewapend met het arsenal aan moderne wetenschappelijke hulpmiddelen dat ons tegenwoordig ten dienste staat en mede door middel warvan reeds geavanceerde studies zijn verschenen, zal in dat geval het dwalen van de rechtshistoricus in de antieke tuinen van Themis de toenmalige matschappelijke realiteit nog dichterbij ons kunnen brengen. 
Min diepe erkentelikheid gat uit naar het Bestur wan de Sticlingh Wetenschappelijk Onderzoek Limburg voor het initiatief om an de Rijksuniversiteit Limburg een bijzondere leerstoel Algemene rechtsgeschiedenis in het leven te roepen, en evenzeer voor het besluit mij to bezeting ervan te benoemen. Dat de Faculteit der Rechusgelcerdheid deze benoeming een draagwlak verleent, vervult mij met vreugde, angezien de innige relatie die ik sedert 1983 met har onderhoud, daurdoor geformaliseend kon worden. Min streven blift erop gericht binnen het beperkte tijdsbestek dat mij voor de vervulling van mijn werkzamheden ter beschikking staat, met degenen die her angaar, in goed overleg en binnen het bestaade onderwijskundige beleidskader, een programma van wetenschappelijk onderzoek en onderwijs se ontwikkelen, daarbij vertrouwende op een brede consensus in de Faculteit. In dit streven sta ik gelukkig niet alleen. Bestond wellicht bij de "decisionmakers' in de Stichring en de Faculteit een gewoll voor het door Neratius Priscus geformuleerde adagium, zoals dat geciteerd wordt door Marcellus in Dig. 50,16,85: Tres facimal collegiwm? Hoewel bij de start wan de Faculteit de overtuiging bestond aan de rechtsgeschiedenis wiet of nawweliks andacht te besteden, geniet ik immers nu al het voorrecht met twee (rechts)historici - Prof. Mr. A.F.L. Gehlen en Drs. L. Berkvens - te mogen samenwerken. Ik weet dat ik in Nederland niet alleen sta in mijn respect voor de dynamische anpassingsbereidheid en de onverveerde 'open mind" van de jonge Faculteit om het werkgebied der rechtsgeschiedenis dat elders zijn waarde voor de scholing in het juridisch denken al sedert generaties heeft bewezen, alsnog onder har beschermende hand te brengen.

$\mathrm{U}$, waarde Gehlen, auteur van eminente studies over rechtsgeschiedenis van deze regio en praktisch beofenaar van de oeroude ars notariatus naast mij te weten, is mij een sterke steun. En ter andere zijde U, wawde Berkwens, integer ijveraar voor onze professie: op deze Maastrichtse academische Olympus fungeert $U$ bij uirstek steeds als mijn Hermes - niet gehelmd en met vleugels aan de voeten, maar met ogen gelijk Argus, met oren gelijk Midas - die mii tijding brengt omtrent woor de rechtsgeschiedenis relevante bewegingen.

Vanaf deze plats zou ik voorts een warm woord van vriendschap en respect willen laten opklinken voor de medewerkers met wie ik in het Sticht het onverbiddelijk proces van verzilting van onze rechtshistorische gronden het hoofd tracht te bieden. Zolang de dijken niet breken en onze omheiningen net geheel worden neergehald, zullen wij in onze tuin bijven zaaien en oogsten in de wetenschap dat ons exquise produkr leder jaar onder academi sche finproevers weer afnemers vindt. 
In de twee jaar dat ik, waar mogelik in relatie tot eigentijdse problemara, $U$. dames en beren studenten, in anaking heb gebracht met uiteenlopende aspecren van de Romeinse en Nederlandse rectutsgeschiedenis, hoop if U enigszins overuigd te hebben van de warde van deze discipline als component van het wierjarige rechtsgeleerde studieprogramma. Over detailvagen omerent de doelstellingen die ik idealiter met $U$ zou willen nastreven, heb ik op verzoek van $U_{w}$ pas afgestudeerde commilitones kort geleden aan deze Faculteit een omstandig exposé gehouden; naar de gedrukte versie daarvan zou ik $U$ willen verwijzen. ${ }^{154}$ Voor de rechtsgeschiedenis als essentieel bestanddeel in het juridisch curriculum, mer mame voor aankomende juristen, wil ik mij gatarne beroepen op de autoriteit van de klassiek-Romeinse jurist Gaius, waar hij schrift: "als men het, bij wijze van spreken, van degenen die woor een rechtbank hun zaken bepleiten, al voor een doodzonde houdt een rechter de zak zonder inleidende opmerkingen uiteen te zetten, hoevel te meer ongepast zou het dan zijn voor iemand die een exegese toezegt, om plompverloren onder weglating van her begin en zonder de oorsprong op te sporen - om zo te zeggen met ongewassen handen - het onderwerp van zijn verklarend exposé te behandelen. Want als ik mij niet vergis, wekken dit soort inleidingen ons op de voorliggende stof met meer plezier te lezen en warborgen zij ons een veel helderder begrip, wanneer wij zijn aangekomen op her punt war het om gaat.' 155

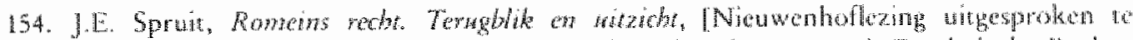

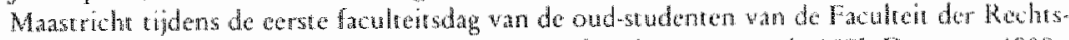

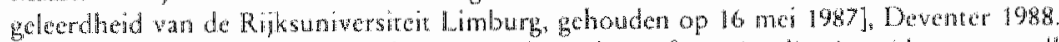

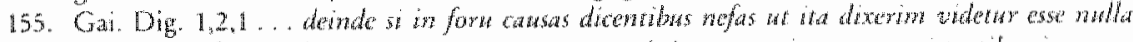

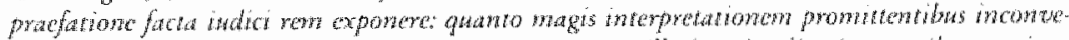

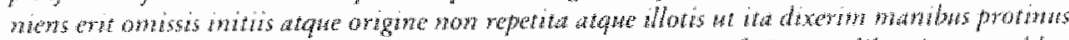

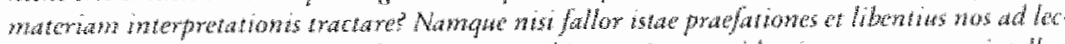

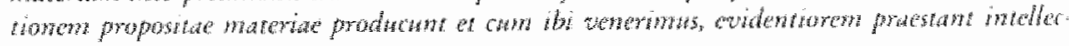
them. 


\section{Colofon}

De rekst wrd op 9 juni 1989 slechts gededtelijk uirgesproken.

Het binnenwerk werd gezet uit het lettertype Garamond corps 10 op 12 punten door Loonzetterij Abé te Hoogeveen.

Het binnenwerk werd gedrukt door Drukkerij Tulp BV te Zwolle op houtvrij romandruk blauw-wit $90 \mathrm{~g} / \mathrm{m}^{2}$, opdikking 0.20 wan Proosi en Brandt BV.

Het onslag is gedrukt door Drukkerij Tulp BV te Zwolle op Invercote 240 $\mathrm{g} / \mathrm{m}^{2}$ van Proost en Brandr BV.

Het bindwerk werd verzorgd door Kramer Boekbinders BV te Apeldoorn.

Voor het omslag is gebruik gemaakt van een fresco uit Pompeji.

De op pagina 24 en 25 afgebeelde gravure is ontleend aan Hortorum viridario. rumque elegantes et multiplicis fonnae ad architectonicae artis normam affabre. delineatae a lobanne Vredmanno Frisio, Antwerpen 1583.

De auteur betuigt voor de totstandkoming van deze uitgave gaarne zijn dank aan Kluwer BV (Deventer), de Stichring Wetenschappelijk Onderzoek Limburg (Maastricht) en de Aemilius Papinianus Stichting (Utrecht).

De vertalingen in de tekst dankt de auteur aan Dr. W.E.M. Klostermann (Uirecht). 